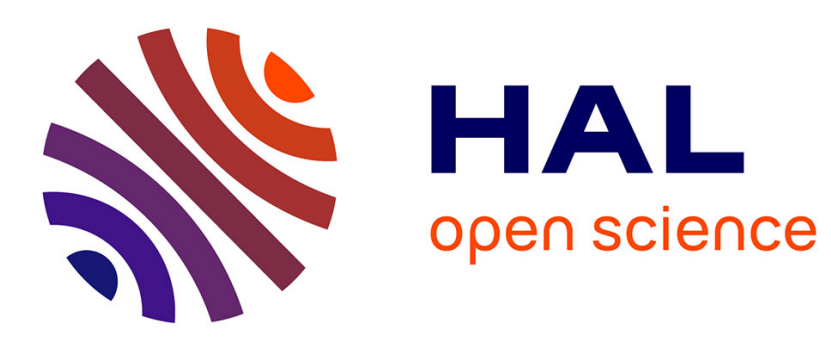

\title{
G protein-coupled receptor heteromers are key players in substance use disorder.
}

\author{
Lyes Derouiche, Dominique Massotte
}

\section{To cite this version:}

Lyes Derouiche, Dominique Massotte. G protein-coupled receptor heteromers are key players in substance use disorder.. Neuroscience and Biobehavioral Reviews, 2019, 106, 10.1016/j.neubiorev.2018.09.026 . hal-02264889

\section{HAL Id: hal-02264889 \\ https://hal.science/hal-02264889}

Submitted on 18 Mar 2020

HAL is a multi-disciplinary open access archive for the deposit and dissemination of scientific research documents, whether they are published or not. The documents may come from teaching and research institutions in France or abroad, or from public or private research centers.
L'archive ouverte pluridisciplinaire HAL, est destinée au dépôt et à la diffusion de documents scientifiques de niveau recherche, publiés ou non, émanant des établissements d'enseignement et de recherche français ou étrangers, des laboratoires publics ou privés. 


\title{
G Protein-Coupled Receptor Heteromers Are Key Players in Substance Use Disorder.
}

\author{
Lyes Derouiche and Dominique Massotte* \\ Institut des Neurosciences Cellulaires et Integratives, UPR 3212 \\ 5 rue Blaise Pascal, F-67000 Strasbourg, France
}

\section{Highlights}

- Heteromers are functional entities with behavioral impact

- Heteromers are increasingly recognized as key players in substance use disorder

- Heteromers may be part of larger functional multiprotein complexes

- Heteromers represent emerging innovative therapeutic targets

\section{Funding sources:}

The work was received the financial support of the Fondation pour la Recherche Médicale (DPA20140129364), the CNRS and the University of Strasbourg. L. Derouiche was the recipient of an IDEX post-doctoral fellowship of the University of Strasbourg.

\footnotetext{
* Author for correspondence :

Dominique Massotte, INCI UPR 3212, 5 rue Blaise Pascal, F-67000 Strasbourg, France, email: d.massotte@unistra.fr
} 


\begin{abstract}
G protein-coupled receptors (GPCR) represent the largest family of membrane proteins in the human genome. Physical association between two different GPCRs is linked to functional interactions which generates a novel entity, called heteromer, with specific ligand binding and signaling properties. Heteromerization is increasingly recognized to take place in the mesocorticolimbic pathway and to contribute to various aspects related to substance use disorder. This review focuses on heteromers identified in brain areas relevant to drug addiction. We report changes at the molecular and cellular levels that establish specific functional impact and highlight behavioral outcome in preclinical models. Finally, we briefly discuss selective targeting of native heteromers as an innovative therapeutic option.
\end{abstract}

\title{
Keywords
}

addiction, substance use disorder, G protein-coupled receptors, heteromers, rodents, opioid, cannabinoid, dopamine, cocaine, adenosine, psychostimulant, alcohol 


\section{Introduction}

Drug addiction or Substance Use Disorder (SUD) is a multifactorial disease that emerges from the combination of genetic predisposition, socio-economic environment and the nature of the drug itself. Addiction develops from initial recreational drug use but also emerges following misuse amd/or abuse of prescription drugs after an initial therapeutic use or in patients that self-medicate. It progresses towards compulsive drug seeking and consumption until this excessive behavior cannot be controlled despite adverse consequences to an individual's social and professional life. In addition, negative emotional states, such as anxiety and irritability, characterize abstinence. Therefore, maintaining long-term abstinence is the major challenge to be faced by addicts and SUD is now recognized as a chronic relapsing neuropsychiatric disorder (Koob and Volkow, 2010).

All drugs alter dopaminergic tone by promoting activation of the mesocorticolimbic pathway. This neurocircuit consists of dopaminergic projections from the ventral tegmental area (VTA) to the nucleus accumbens (Nacc), amygdala and prefrontal cortex (PFC). Glutamatergic projections from the PFC also contribute to the core regulation process of this pathway. Additional brain areas then modulate the activity of this circuit in response to external stimuli such as spatial (hippocampus) and non-spatial (amygdala) cues, or internal states (amygdala, hypothalamus, raphe nuclei) (Figure 1). Importantly, addiction is now acknowledged to also develop in response to behavioral patterns such as gambling or excessive food consumption. In these pathologies, endogenous opioid and/or endocannabinoid peptides are released that activate their cognate receptor to stimulate the dopaminergic mesocorticolimbic pathway as observed for exogenous drugs of abuse (Noori et al., 2016).

Despite common modulation of the mesocorticolimbic pathway, the molecular targets of drugs of abuse differ significantly. Opiates, tetrahydrocannabinol (THC) or the psychostimulants caffeine or hallucinogen lysergic acid diethylamide (LSD) bind to G protein- 
coupled receptors (GPCR), namely the opioid, cannabinoid, adenosine or serotonin receptors respectively. Alcohol mainly targets ligand-gated channels whereas psychostimulants such as amphetamines or cocaine modulate the dopamine transporter. Accordingly, pharmacological approaches have revealed that SUD is a complex process and that drug induced neuroplasticity covers multiple aspects including interactions triggered between different neuromodulatory systems. Cross-talk can take place at the molecular level through direct interactions between two GPCRs. This gives rise to a novel entity, a heteromer, which is characterized by specific ligand binding, signaling and/or trafficking properties. Cross-talk can also occur at the cellular level through simultaneous activation of several signaling cascades and at the integrated level through concomitant involvement of distinct neuronal circuits. Moreover, interactions can simultaneously occur at the three levels adding complexity to the ways in which drugs of abuse exert their effects.

Here, we review native heteromers formed by associations of two GPCRs or by association of a GPCR with an ion channel, in brain areas related to SUD. We focus on in vivo functional alterations and highlight behavioral consequences. We also include data collected in co-transfected cells that provide insight into the heteromerization process or add to our comprehension of heteromer signaling. Finally, we briefly address the potential of these heteromers as novel therapeutic targets.

\section{The concept of heteromerization in GPCRs}

All GPCRs have a common architecture made of seven $\alpha$-helical transmembrane domains (TM) and possess an extracellular N-terminus and intracellular C-terminus. Specific recognition of the ligands takes place in the extracellular N-terminus and loops, but ligand binding also requires docking in a pocket within the helical bundle. Binding of an agonist leads 
to receptor activation which in turn affects interaction with intracellular partners and initiates multiple downstream signaling events.

Based on specific structural determinants, GPCRs are usually sorted into five different classes with classes A, B, C and F being expressed in mammals (Fredriksson and Schioth, 2005). GPCRs exhibit a high propensity to aggregate (Salim et al., 2002), which raised the question of criteria for a minimal functional unit. About 20 years ago, functional $G A B A_{B}$ receptors from class C GPCRs were shown to require mandatory association of $\mathrm{GABA}_{\mathrm{B} 1}$ and $\mathrm{GABA}_{\mathrm{B} 2}$ receptors to be functional (Jones et al., 1998). Obligatory dimerization has subsequently been shown for other class C GPCRs such as the metabotropic glutamate receptors or the taste receptors (Rondard et al., 2011). In contrast, several class A GPCRs including rhodopsin, $\beta 2$ adrenergic, neurotensin 1 , leukotriene $B_{2}$ or mu opioid receptors are able to bind ligands, activate $G$ proteins and recruit $\beta$-arrestin or $G$ protein kinases in a monomeric form when reconstituted in a lipidic environment (reviewed in (Vischer et al., 2015)). The ability of a receptor to initiate signaling cascades as a monomeric entity does not however preclude interaction with other monomers from the same or a different receptor type to form a larger functional complex. For example, two monomers were found associated with one heterotrimeric $\mathrm{G}$ protein in the case of the serotonin $5 \mathrm{HT}_{4}$ receptor (Pellissier et al., 2011). Activation of one monomer was enough to stimulate the $\mathrm{G}$ protein but co-activation led to a positive cross-talk indicating that this receptor rather functions as a homodimer. Similarly, the minimal signaling unit of the dopamine $\mathrm{D}_{2}$ receptor was defined as homodimer. Here again, activity was maximal upon agonist binding to one monomer but was modulated by the constitutive activity of the second monomer indicating asymmetric functional interaction (Han et al., 2009). Whether the minimal functional unit involves a monomer or a homodimer thus appears receptor dependent (reviewed in (Ferre et al., 2014)). 
In native tissue, class A GPCRs usually form clusters where they functionally interact with the surrounding receptors forming the so-called homomers if only one receptor type is present or heteromers if associated with a different receptor/protein (Khelashvili et al., 2010).

Heteromers have been extensively studied in co-transfected cells using biochemical, biophysical, or pharmacological approaches often combined with generation of mutant receptors (for reviews see (Fernandez-Duenas et al., 2012; Maggio et al., 2013; Vischer et al., 2015). Early on, major efforts were invested to overcome technical limitations and validate their existence in native tissue. In 2007, the International Union of Basic and Clinical Pharmacology defined criteria for validation of heteromer formation in class A GPCRs (Pin et al., 2007) comprising three main criteria:

1) There should be evidence for physical association in native tissues or primary cells. This can be obtained by co-immunoprecipitation, co-localization with antibody at electron microscopic level or energy transfer technologies using labeled ligands or knock-in animals. The use of the proximal ligation assay (PLA), developed more recently, is also widely accepted as appropriate to detect in situ receptor physical proximity.

2) In native tissues, heteromerization must induce a specific functional property, either a new pharmacological profile and/or the activation of a specific transduction cascade, distinct from those induced by each receptor expressed alone.

3) Disruption of the physical interaction (knock-out animals, RNA $\mathrm{R}_{\mathrm{i}}$ technology, interfering peptide) must drastically alter the specific functional properties assigned to heteromers.

In the past years, our understanding of the functional impact of in vivo heteromerization has significantly improved and the concept has gained acceptance. Next to heteromer formation involving two class A GPCRs, heteromer formation between class A and class C GPCRs or between GPCRs and other proteins such as ion channels have also been reported. 
This, in turn, has introduced an additional level of complexity in our interpretation of the behavioral responses observed upon receptor activation but has also expanded the repertoire of tools enabling modulation of cellular activity and physiological pathways.

\section{Modulation of striatal dopaminergic transmission by heteromers}

Dopamine transmission in the striatum is central to SUD though modulated in different ways by drugs of abuse. Opiates, cannabis and alcohol, impact the core VTA-Nacc dopaminergic axis by reducing GABAergic tonic inhibition on dopamine release whereas psychostimulants modulate the activity of dopaminergic receptors in the basal ganglia both contributing to the reinforcing effect of a drug. In the striatum, medium spiny neurons (MSN) play a crucial role in this process by integrating information and propagating it through two main output pathways (Figure 2A). The direct striato-nigral pathway projects to the internal globus pallidus and substantia nigra $(\mathrm{SN})$ and expresses dopamine $\mathrm{D}_{1}$ receptors together with dynorphin and substance $\mathrm{P}$. The indirect striato-pallidal pathway projects to the external globus

pallidus and expresses dopamine $\mathrm{D}_{2}$ receptors together with enkephalins (Tepper et al., 2007). More recently, a third striatal output has been postulated which is composed of a discrete neuronal population of the ventral striatum, mostly in the Nacc shell. These neurons co-express $\mathrm{D}_{1}$ and $\mathrm{D}_{2}$ receptors, dynorphin, enkephalin, GABA, and glutamate and may project to the $\mathrm{SN}$ and VTA (Perreault et al., 2012a). Importantly, each pathway expresses a combination of postsynaptic GPCRs coupled to inhibitory Gai/o or excitatory Gas subunits, providing the opportunity to further modulate neuronal activity through receptor heteromerization (Figure 2B).

\section{Class A-class A heteromers with established modulatory role in SUD}


Here, we review functional properties of heteromers showing altered expression levels upon drug exposure and/or specific impact on behaviors related to SUD (Figure 3).

\subsection{Adenosine $A_{2 a}$-dopamine $D_{2}$ heteromers}

Heteromerization of adenosine $\mathrm{A}_{2 \mathrm{a}}$ and dopamine $\mathrm{D}_{2}$ receptors has been extensively studied in native tissue. Close physical proximity of $\mathrm{A}_{2 \mathrm{a}}$ and $\mathrm{D}_{2}$ receptors was detected by in situ PLA in the striatum of C57BL6/J mice (He et al., 2016; Trifilieff et al., 2011) and confirmed in rats by electron microscopy and time-resolved fluorescence resonance energy transfer (FRET) (Fernandez-Duenas et al., 2015). Co-internalization was detected upon activation by $\mathrm{D}_{2}$ or $\mathrm{A}_{2}$ agonists in SHSY5Y neuroblastoma and in primary striatal neurons (Hillion et al., 2002; Huang et al., 2013). Bivalent ligands bound to $\mathrm{D}_{2}$ or $\mathrm{A}_{2 \mathrm{a}}$ receptors with higher affinity than the corresponding monovalent control ligands in striatal membranes but not in membranes expressing one receptor only suggesting synergistic binding at $A_{2 a}-D_{2}$ heteromers (Soriano et al., 2009), which supports close physical proximity of $A_{2 a}$ and $D_{2}$ receptors.

Remarquably, changes in the extent of physical association between $A_{2 a}$ and $D_{2}$ receptors were reported in several behavioral paradigms relevant to SUD. Psychostimulants induce sensitization of the dopaminergic system and progressively disrupt goal directed behaviors in favor of goal insensitive habitual responding (Furlong et al., 2017). This transition is facilitated by $D_{1}$ receptor activation and inhibited by $D_{2}$ receptors. In the striatum of C57BL6/J mice, $A_{2 a}-D_{2}$ heteromers were more abundant in the dorsolateral than in the dorsomedial striatum in basal conditions (He et al., 2016; Trifilieff et al., 2011). However, in situ PLA revealed higher signal in the dorsomedial and dorsolateral striatum in a paradigm of habit formation (random interval training) whereas it remained unchanged in a paradigm of goal directed behavior (random ratio training) (He et al., 2016). This suggests that $A_{2 a}-D_{2}$ 
heteromers participate in the negative regulation of $D_{2}$ signaling in the striatum and contribute to the control of abnormal habit formation taking place during drug addiction especially during relapse. This view is in line with accelerated habit formation following methamphetamine sensitization observed when $\mathrm{D}_{2}$ receptors are pharmacologically blocked before instrumental learning (Nelson and Killcross, 2013). Moreover, these animals were unable to inhibit responding in extinction and reacquisition phases even when they acquired an aversion to the reinforcer (Nelson and Killcross, 2013). $\mathrm{A}_{2 \mathrm{a}}-\mathrm{D}_{2}$ heteromers may therefore also contribute to the development of compulsive behaviors.

In a model of cocaine self-administration, in situ PLA revealed increased $\mathrm{A}_{2 \mathrm{a}}-\mathrm{D}_{2}$ heteromers in the Nacc shell but not in the dorsal striatum of rats (Borroto-Escuela et al., 2017). Injection of the $A_{2 a} T M V$ peptide in the Nacc disrupted the $A_{2 a}-D_{2}$ heteromers as shown by decreased in situ PLA signal (Borroto-Escuela et al., 2018). It also suppressed the inhibitory effect of the $\mathrm{A}_{2 \mathrm{a}}$ agonist CGS21680 on cocaine self-administration (Borroto-Escuela et al., 2018), in agreement with reports demonstrating that reinstatement of cocaine selfadministration is decreased or favored by $\mathrm{A}_{2 \mathrm{a}}$ agonists or antagonists respectively (O'Neill et al., 2012).

Dynamical changes have also been described in a model of voluntary alcohol intake (intermittent access to $20 \%$ alcohol for at least 12 weeks), which led to higher detection of $\mathrm{A}_{2 \mathrm{a}^{-}}$ $\mathrm{D}_{2}$ heteromers in the Nacc shell and dorsal striatum by in situ PLA (Feltmann et al., 2018). This is in line with the regulation of ethanol's rewarding effect in mice by $A_{2 a}$ receptors expressed in striatopallidal neurons (Arolfo et al., 2004). Ethanol interacts directly with the adenosine system by blocking nucleoside transporters in the cell membrane. More specifically, ethanol selectively inhibits the type 1 equilibrative nucleoside transporter (ENT1) leading to decreased levels of striatal adenosine (Dunwiddie and Masino, 2001). Using ENT1 knock-out mice to mimic reduced adenosine availability, Nam et al. (2013) showed that dampening $A_{2 a}$ 
signaling in the dorsomedial striatum promoted ethanol seeking behaviors through decreased CREB activity and enhanced goal-oriented behaviors, hence contributing to excessive ethanol drinking (Nam et al., 2013). Ethanol also decreased ENT1 expression in the Nacc where reduced levels of adenosine could contribute to ethanol dependence and tolerance (Nam et al., 2013). In line with these observations, mice lacking $A_{2 a}$ showed reduced sensitivity to the hypnotic effects of alcohol, increased alcohol consumption and reduced alcohol-withdrawal seizures (El Yacoubi et al., 2001). At the level of $A_{2 a}-D_{2}$ heteromers, reduced $A_{2 a}$ activity would decrease $\mathrm{D}_{2}$ signaling thereby contributing to reduce alcohol withdrawal symptoms but, at the same time, increasing alcohol consumption. Interestingly, the $\mathrm{A}_{2 \mathrm{a}}$ antagonist caffeine is often present as adulterant in the preparation of illicit drugs and in energy drinks consumed in combination with alcohol or other psychostimulants. $\mathrm{A}_{2 \mathrm{a}}-\mathrm{D}_{2}$ heteromers could thus mediate caffeine stimulant effects that would mask some of the acute intoxicating effects of ethanol and promote ethanol seeking behavior (reviewed in (Ferre, 2016).

At the molecular level, the domains at the interface of the two receptors have been widely explored in vitro using a variety of approaches including mutagenesis, receptor chimeras, glutathione S transferase pull-down coupled to mass spectrometry and molecular modeling. The transmembrane domain TM V and third intracellular loop IL3 of the $\mathrm{D}_{2}$ receptor were identified as part of the contact area and were required to observe antagonistic pharmacological interactions (Torvinen et al., 2004) (Borroto-Escuela et al., 2010). More precisely, the arginine cluster 217RRRRKR222 present in the third intracellular loop IL3 of both short $\mathrm{D}_{2 \mathrm{~S}}$ and long $\mathrm{D}_{2 \mathrm{~L}}$ receptor isoforms form electrostatic interactions with two aspartate residues (D401A, D40 2a ) and the phosphorylated $\mathrm{S} 374$ residue in the $\mathrm{A}_{2 \mathrm{a}} \mathrm{C}$-terminus (BorrotoEscuela et al., 2010; Ciruela et al., 2004).

Recently, a functional heterotetramer composed of $\mathrm{D}_{2}-\mathrm{D}_{2}$ and $\mathrm{A}_{2 \mathrm{a}}-\mathrm{A}_{2 \mathrm{a}}$ homomers has been proposed to integrate the experimental data collected over the years (Borroto-Escuela et 
al., 2016; Fuxe et al., 2010; Navarro et al., 2014; Taura et al., 2017) and, in particular, the psychostimulant effects of the $\mathrm{A}_{2 \mathrm{a}}$ antagonist caffeine (Ferre et al., 2018) (Figure 4). In the heterotetramer, the transmembrane domain TM VI is present at the interface between $A_{2 a}-A_{2 a}$ or $\mathrm{D}_{2}-\mathrm{D}_{2}$ receptor homomers and transmembrane domains IV and V contribute to the $\mathrm{A}_{2 \mathrm{a}}-\mathrm{D}_{2}$ heteromeric interface (Navarro et al., 2018b). This macromolecular complex is pre-coupled to the partner G proteins and two adenylate cyclase AC5 molecules and undergoes dynamic reorganization upon agonist binding (Navarro et al., 2018b).

\subsection{Dopamine $\mathrm{D}_{2}$ - sigma1 receptor heteromers}

The sigmal receptor was originally wrongly classified within the opioid receptor family. The recently solved 3D crystal structure revealed a trimeric protein with one transmembrane domain in each protomer. (Schmidt et al., 2016). This ubiquitous protein intervenes in various cellular functions, is predominantly located in the endoplasmic reticulum (ER) but has also been detected at the plasmalemma and in synaptosomal fractions (recently reviewed in (Sambo et al., 2018)). In addition, the sigma1 receptor has an affinity of about $2 \mu \mathrm{M}$ for cocaine and metamphetamine in rodent brain tissue (Matsumoto et al., 2002; Nguyen et al., 2005).

Physical proximity between the postsynaptic long isoform of the $\mathrm{D}_{2}$ receptor (D2L) and the sigmal receptor was identified by in situ PLA and co-immunoprecipitation in the mouse striatum (Navarro et al., 2013). In a protocol of cocaine self-administration, dopamine $\mathrm{D}_{2^{-}}$ sigmal proximity was increased in the rat Nacc shell and decreased in the dorsal striatum as shown by in situ PLA (Borroto-Escuela et al., 2017). Since cocaine similarly affected $A_{2 a}-D_{2}$ and $\mathrm{D}_{2}$-sigmal heteromers in the two regions, one can postulate that the three proteins associate into larger $\mathrm{A}_{2 \mathrm{a}}-\mathrm{D}_{2}$-sigmal heterocomplexes. Interestingly, direct action of $150 \mu \mathrm{M}$ cocaine in $\mathrm{CHO}$ cells devoid of dopamine transporter but endogenously expressing the sigmal receptor 
(Mei and Pasternak, 2001) led to decreased BRET signal between co-expressed A2 and D2 receptors (Marcellino et al., 2010). This strongly suggests that cocaine concentrations compatible with those measured in cocaine abusers could affect the conformation of the $\mathrm{A}_{2 \mathrm{a}^{-}}$ $\mathrm{D}_{2}$-sigma1 heterocomplex.

From a functional point of view, co-administration of cocaine and the $\mathrm{D}_{2} / \mathrm{D}_{3}$ agonist quinpirole decreased ERK1/2 phosphorylation in the mouse striatum. In contrast, cocaine did not induce ERK1/2 phosphorylation and could not modify the level of ERK1/2 phosphorylation induced by quinpirole in sigmal knock-out mice (Navarro et al., 2013). Moreover, in the presence of sigmal antagonists (PD144418 or BD1063), cocaine effects were reduced, and cocaine failed to amplify the effects of the agonist quinpirole on $\mathrm{K}^{+}$evoked dopamine and glutamate release from striatal synaptosomes (Beggiato et al., 2017; Navarro et al., 2013). Altogether, data therefore support a functional role for $\mathrm{D}_{2}$-sigmal heteromers in the effects of cocaine.

Expression of $\mathrm{D}_{2}$-sigmal heteromers is also modulated by chronic alcohol suggesting a more general implication in SUD. In a model of voluntary alcohol consumption with intermittent access to $20 \%$ ethanol, a decrease in PLA signal for $\mathrm{D}_{2}$-sigma1 heteromers was observed in the dorsal striatum where it was paralleled by a decrease in $\mathrm{D}_{2}-\mathrm{D}_{2}$ homomers and an increase in $\mathrm{A}_{2 \mathrm{a}}-\mathrm{D}_{2}$ heteromers (Feltmann et al., 2018).

\subsection{Dopamine $D_{1}$ - dopamine $D_{2}$ heteromers}

In the basal ganglia, the strict separation in $\mathrm{D}_{1}$ and $\mathrm{D}_{2}$ receptor expression patterns has been challenged by the description of a subset of striatal MSNs co-expressing $D_{1}$ and $D_{2}$ receptors, dynorphin, enkephalin, GABA and glutamate (Hasbi et al., 2011) (Perreault et al., 2012b). 
Heteromerization of $\mathrm{D}_{1}$ and $\mathrm{D}_{2}$ dopamine receptors was then hypothesized. To support this view, S. George and collaborators accumulated evidence of $\mathrm{D}_{1}-\mathrm{D}_{2}$ physical proximity. First, FRET signal was detected on primary striatal cultures between secondary antibodies coupled to the AlexaFluor 350 to localize $\mathrm{D}_{2}$ receptors and secondary antibodies coupled to the AlexaFluor 488 to localize $\mathrm{D}_{1}$ receptors suggesting co-localization within the same membrane domains (Verma et al., 2010). Using FRET efficiency, the proximity of $\mathrm{D}_{1}$ and $\mathrm{D}_{2}$ receptors was estimated to 5-7 nm in clusters located at the surface of MSNs in the Nacc core (Hasbi et al., 2009; Perreault et al., 2016). In vivo $\mathrm{D}_{1}-\mathrm{D}_{2}$ physical proximity was also confirmed by in situ FRET approaches in the rat striatum (Hasbi et al., 2018). Co-immunoprecipitation from striatal rat brain (Hasbi et al., 2009; Lee et al., 2004) and human striatum (Pei et al., 2010) further supported close receptor proximity. More recently, endogenous $D_{1}-D_{2}$ heteromers were visualized using in situ PLA in primary striatal cultures and Nacc from rat (Perreault et al., 2016) as well as in the Nacc shell from the long-tail macaque (Perreault et al., 2016; Rico et al., 2017). More specifically, about $30 \%$ of the MSNs in the rat Nacc shell and more than $20 \%$ in the rat Nacc core expressed $D_{1}-D_{2}$ heteromers at the cell surface versus only $5 \%$ of the MSNs in the dorsal striatum as revealed by in situ PLA with labeled primary antibodies (Hasbi et al., 2018). Using the same approach, no $D_{1}-D_{2}$ heteromers were detected in the mouse striatum of mice deficient for either receptor (Hasbi et al., 2018). At the molecular level, heteromerization would take place between two adjacent arginine residues located on the $\mathrm{D}_{2}$ third intracellular loop IL3 and two adjacent glutamic acid residues located on the $\mathrm{D}_{1} \mathrm{C}$-terminal tail (O'Dowd et al., 2012). Accordingly, a TAT- $\mathrm{D}_{1}$ peptide encoding the critical portion of the $\mathrm{D}_{1} \mathrm{C}$-terminus disrupted $\mathrm{D}_{1}-\mathrm{D}_{2}$ co-immunoprecipitation (Perreault et al., 2016) and abolished the PLA signal (Hasbi et al., 2018) in the rat striatum.

Functionally, $D_{1}-D_{2}$ heteromers would specifically signal through $\mathrm{G} \alpha \mathrm{q} / 11$ leading to CAMKII activation, intracellular calcium release and increased BDNF expression when co- 
activated by the $\mathrm{D}_{1}$ agonist SKF81297 and the $\mathrm{D}_{2}$ agonist quinpirole or when activated by the selective $\mathrm{D}_{1}-\mathrm{D}_{2}$ agonist SKF83959 (Hasbi et al., 2009; Lee et al., 2004; Perreault et al., 2016; Rashid et al., 2007). Activation of this signaling cascade was disrupted by the TAT- $\mathrm{D}_{1}$ peptide encoding the critical portion of the $\mathrm{D}_{1} \mathrm{C}$-terminus thereby establishing dependence on $\mathrm{D}_{1}-\mathrm{D}_{2}$ receptor interaction (Perreault et al., 2016). Increased BDNF expression suggests an impact on maturation and differentiation of striatal neurons which could account for drug-induced plasticity.

Recently, the role of $\mathrm{D}_{1}-\mathrm{D}_{2}$ heteromerization on several behavioral outputs related to cocaine consumption was uncovered using disruption of $\mathrm{D}_{1}-\mathrm{D}_{2}$ heteromers by the TAT- $\mathrm{D}_{1}$ peptide in the rat striatum (Hasbi et al., 2018; Perreault et al., 2016). This approach provided convincing evidence that activation of $D_{1}-D_{2}$ heteromers by the $D_{1}-D_{2}$ agonist SKF83959 blocked acquisition and expression of cocaine induced CPP whereas disruption of striatal $\mathrm{D}_{1}$ $\mathrm{D}_{2}$ heteromers potentiated conditioned place preference to cocaine (Hasbi et al., 2018; Perreault et al., 2016). Similarly, behavioral sensitization induced by repeated exposure to cocaine, which is characterized by an augmented locomotor response to a subsequent psychostimulant challenge injection, was abolished by the $\mathrm{D}_{1}-\mathrm{D}_{2}$ agonist SKF83959 and potentiated by the disruption of striatal $\mathrm{D}_{1}-\mathrm{D}_{2}$ heteromers (Hasbi et al., 2018; Perreault et al., 2016). Moreover, activation of $D_{1}-D_{2}$ heteromers by the $D_{1}-D_{2}$ agonist SKF83959 abolished cocaine selfadministration and reinstatement to cocaine seeking whether promoted by drug priming or cue association (Hasbi et al., 2018). Again, disrupting $\mathrm{D}_{1}-\mathrm{D}_{2}$ physical interactions led to an opposite phenotype with potentiation of both drug self-administration and reinstatement (Hasbi et al., 2018). Western blot and immunohistochemical analyses in the NAcc revealed that activation of the $D_{1}-D_{2}$ heteromer likely counteracted cocaine-induced ERK phosphorylation and $\Delta$ Fos $\mathrm{B}$ accumulation and reduced cocaine evoked field potentials signals by increasing the phosphorylation of DARPP32 at the Thr75 residue (Hasbi et al., 2018). 
Interestingly, $\mathrm{D}_{1}-\mathrm{D}_{2}$ heteromer expression increases with age as it is less abundant in the caudate putamen and in the Nacc shell, but not in the Nacc core, of juvenile rats compared to adults (Perreault et al., 2010; Perreault et al., 2012b; Perreault et al., 2016). This increase in expression was paralleled by increased Gaq coupling in 8-month-old rats compared to 3month-old animals despite no change in individual receptor expression (Rashid et al., 2007). Data therefore suggest a shift towards $\mathrm{D}_{1}-\mathrm{D}_{2}$ Gaq coupling with age and lower $\mathrm{D}_{1}-\mathrm{D}_{2}$ tonic inhibition in juvenile animals. This may account for the increased susceptibility to cocaine's behavioral effects observed in adolescents (Spear, 2016) and is in line with the observation that behavioral sensitization to psychostimulants such as cocaine requires activation of both $D_{1}$ and $\mathrm{D}_{2}$ receptors (Capper-Loup et al., 2002) and CAMKII (Pierce et al., 1998) in the Nacc.

Importantly, the implication of $\mathrm{D}_{1}-\mathrm{D}_{2}$ heteromers is not restricted to cocaine but extends to natural reinforcers. Indeed, activation of $D_{1}-D_{2}$ heteromers by the $D_{1}-D_{2}$ agonist SKF83959 reduced sucrose preference in a two-bottle free choice paradigm whereas heteromer disruption with the TAT- $\mathrm{D}_{1}$ peptide had the opposite effect (Hasbi et al., 2018). In addition, in a paradigm of restricted food access, activation of $D_{1}-D_{2}$ heteromers reduced the motivation to seek and consume palatable food (Hasbi et al., 2018).

\subsection{Mu opioid-dopamine $D_{1}$ heteromers}

Co-immunoprecipitation of $\mathrm{mu}$ opioid and dopamine $\mathrm{D}_{1}$ receptors in striatal membranes from wild type, but not from $\mathrm{D}_{1}$ or mu receptor knock-out mice, established the physical proximity of the two receptors (Tao et al., 2017). The $\mathrm{D}_{1}$ antagonist SCH23390 reduced mu opioid receptor signaling as revealed by reduced $\mathrm{G}$ protein activation, decreased ERK1/2 phosphorylation and less c-Fos induction in wild type but not $\mathrm{D}_{1}$ knock-out mice (Tao et al., 2017). These data are indicative of the cross-antagonism exerted by $D_{1}$ antagonists on mu opioid signaling. Accordingly, chronic systemic co-administration of the $\mathrm{D}_{1}$ antagonist 
SCH23390 and the mu agonist morphine reduced morphine induced hyperlocomotion, sensitization acquisition and expression (Tao et al., 2017). Systemic administration or local infusion in the Nacc of the $\mathrm{D}_{1}$ antagonist SCH23390 also decreased expression of the locomotor sensitization to the mu agonists morphine and DAMGO (Tao et al., 2017). Similarly, morphine or DAMGO induced locomotor sensitization was markedly decreased upon intra Nacc injection of an ERK inhibitor (Tao et al., 2017). $D_{1}$ impact was independent of dopaminergic transmission from the VTA as it was also observed in rats with 6-OHDA lesion in the NAcc (Tao et al., 2017). Finally, no locomotor sensitization to morphine was observed in knock-out mice deficient for the $\mathrm{D}_{1}$ receptor (Tao et al., 2017). Altogether, data establish that $m u-D_{1}$ heteromers play a critical role in opiate hyperlocomotion and locomotor sensitization.

\subsection{Mu-delta opioid heteromers}

Mapping mu and delta opioid receptors in the brain using double fluorescent knock-in mice revealed co-expression in discrete neuronal populations located in subcortical networks essential for survival, including the perception and processing of aversive stimuli (Erbs et al., 2015). Evidence of close physical proximity at the supraspinal level included detection with mu-delta selective antibodies (Gupta et al., 2010), mu-delta co-immunoprecipitation in the hippocampus (Erbs et al., 2015) and antinociceptive activity upon intracerebroventricular (i.c.v.) injection of MDAN-21, a bivalent ligand bridging the mu agonist oxymorphone and the delta antagonist naltrindole (Daniels et al., 2005). Direct physical interaction was shown in the Nacc through disruption by a sequence corresponding to the delta carboxy tail (Kabli et al., 2013), and was also established in the spinal cord through disruption by a peptide corresponding to the mu transmembrane domain TM I (He et al., 2011), and in DRGs through 
disruption with a peptide corresponding to the delta second intracellular loop IL2 (Xie et al., 2009).

Immunohistochemical detection with mu-delta specific antibodies revealed that chronic morphine treatment increased mu-delta heteromer expression in regions associated with the mesocorticolimbic pathway such as the VTA, Nacc, striatum, PFC, hippocampus and, hypothalamus (Gupta et al., 2010), pointing to a modulatory role in SUD. Of note, chronic morphine treatment enhanced delta opioid receptor expression at the cell surface through a mu opioid receptor dependent pathway (reviewed (Gendron et al., 2015)) compatible with mudelta heteromer formation in the ER (Décaillot et al., 2008; Xie et al., 2009). Enhanced delta opioid receptor expression restricted to the circuit of thermal nociception was also reported in the spinal cord in a model of voluntary alcohol consumption (van Rijn et al., 2012) indicating that increase in functional delta receptors could be achieved upon consumption of drugs of abuse other than morphine. Whether the underlying mechanism relies on mu-delta heteromerization however requires further confirmation.

Pharmacological evidence also points to a link between mu-delta heteromers and SUDrelated behaviors. Targeting mu-delta heteromers with the bivalent ligand MDAN-21 (Daniels et al., 2005) or with the biased agonist CYM51010 (Gomes et al., 2013) induced less tolerance and physical dependence compared to morphine. This is in line with high mu-delta coexpression in brainstem nuclei tightly connected to the autonomous system (Erbs et al., 2015) that suggests mu-delta modulation of somatic and autonomic symptoms during drug withdrawal. Moreover, TAN-67, identified as a mu-delta receptor selective agonist in cotransfected HEK 293 cells, decreased ethanol but not sucrose consumption in wild type but not delta receptor knock-out mice (van Rijn and Whistler, 2009).

From a functional perspective, occupancy of the binding site of one receptor increased ligand binding and signaling to the other receptor in SK-N-SH neuroblastoma cells that 
endogenously co-express the two receptors (Gomes et al., 2004; Gomes et al., 2011; Gomes et al., 2000). Interestingly, the nature of the first ligand did not seem important since an agonist, antagonist or inverse agonist induced similar effects. Data therefore suggest that mu-delta heteromerization induced cross-allosteric modulation with a positive cooperativity promoted upon binding of the first ligand. Heterotetramers formed by association of mu homomers with delta homomers have been postulated (Golebiewska et al., 2011), which could accommodate bidirectional cross-allosteric modulation as for $\mathrm{A}_{2 \mathrm{a}}-\mathrm{D}_{2}$ heterotetramers (Bonaventura et al., 2015) (Navarro et al., 2018b).

Co-activation of mu and delta opioid receptors in native tissue also resulted in a positive cross-talk. Indeed, increased hyperpolarization was observed in a subset of GABAergic neurons in VTA slices upon co-application of the delta antagonist TIPP $\psi$ together with mu agonist DAMGO or upon co-application of the mu antagonist CTAP together with the delta agonists deltorphin II or DPDPE (Margolis et al., 2017). Given their enhanced expression in the VTA of morphine dependent animals ((Gupta et al., 2010), Massotte unpublished), mudelta heteromers could thus contribute to increase dopamine release in the Nacc.

Mu-delta heteromerization also alters $\mathrm{G}$ protein coupling. In mu-delta co-transfected $\mathrm{CHO}$ cells, inhibition of forskolin induced cAMP production was maintained after pertussis toxin treatment. This led a postulate that mu-delta heteromers would no longer signal through pertussis toxin sensitive inhibitory Gai/o proteins but would recruit the inhibitory pertussis toxin insensitive Gaz subunit (George et al., 2000). The Gaz subunit is expressed in the striatum and also abundant in the hippocampus (Friberg et al., 1998) where extensive mu-delta heteromerization is present. Gaz is recruited by heroin, morphine, buprenorphine, and methadone (Sanchez-Blazquez et al., 2001). Moreover, mu-delta preferential coupling to Gaz would not be desensitized by chronic morphine administration in the rat striatum and hippocampus (George et al., 2000; Kabli et al., 2014) and Gaz deficient mice show increased 
morphine tolerance (Hendry et al., 2000). These data suggest that Goz dependent mu-delta signaling could also play a role in drug addiction.

Heteromerization not only affects $G$ protein-dependent signaling but also alters $\beta$ arrestin-dependent pathways. In neuroblastoma SKNSH endogenously co-expressing mu and delta opioid receptors, activation by the mu agonist DAMGO led to a spatio-temporal change in the ERK1/2 phosphorylation profile with prolonged activation in the cytoplasmic compartment (Rozenfeld and Devi, 2007). In the presence of the delta selective antagonist TIPP $\psi$, the phosphorylation profile reversed to the one observed for the mu opioid receptor expressed alone (Rozenfeld and Devi, 2007) as expected if dependent on mu-delta heteromerization. The change in ERK1/2 phosphorylation profile was also abolished in the presence of $\beta$-arrestin 2 siRNA (Rozenfeld and Devi, 2007). Efficient recruitment of the $\beta$ arrestin 2 dependent signaling pathway was also observed upon activation by the biased mudelta agonist CYM51010 (Gomes et al., 2013) that promotes co-internalization of mu and delta opioid receptors in primary hippocampal neurons (Derouiche et al., 2018). These results suggest increased cytoplasmic signaling by internalized mu-delta heteromers in line with recent reports on GPCR signaling from the endosomal compartment (Tsvetanova et al., 2015) and indicate changes in the spatiotemporal control of neuronal activity.

\subsection{Mu opioid-Galanin1 heteromers}

$\mathrm{Mu}$ opioid receptors are widely distributed throughout the brain (Erbs et al., 2015). Galanin1 (Gal1) receptors are mostly present in the VTA, Nacc, and SN, suggesting that they may contribute to the galanin-mediated regulation of dopamine neurotransmission (Moreno et al., 2017). Gal1 receptors are also highly expressed in the locus coeruleus, where they may also modulate noradrenergic transmission during opiate withdrawal (Hawes and Picciotto, 2004). Physical proximity between the mu opioid and Gall receptors was established in co-transfected 
cell by BRET and bimolecular fluorescent complementation (Moreno et al., 2017). In the VTA, the mu antagonist CTOP was able to counteract galanin induced ERK1/2, AKT and CREB phosphorylation, a cross-antagonism attributed to mu-Gall heteromers (Moreno et al., 2017). In addition, galanin could not prevent dopamine release promoted by local infusion of the mu agonist endomorphin 1 when mu-Gall heteromers were disrupted by injection of a peptide corresponding to the mu transmembrane domain TM V (Moreno et al., 2017). This suggests a negative cross-talk by which galanin dampens mu opioid receptor signaling. Moreover, enhanced ERK activation was observed in the VTA, Nacc and amygdala in galanin knock-out mice following acute morphine administration compared to wild type mice (Hawes et al., 2008). Importantly, conditioned place preference to morphine was abolished in galanin knockout mice (Hawes et al., 2008). These results therefore substantiate galanin-dependent modulation of the reinforcing properties of opiates. In humans, the single nucleotide polymorphism rs948854 localized in the promoter region of the galanin gene is known to be associated with anxiety related disorders. It may also indicate increased vulnerability to opiate addiction since an increased number of homozygous carriers for the minor allele (G) was detected among opioid addicts (Beer et al., 2013).

\subsection{Cannabinoid $\mathrm{CB}_{1^{-}}$serotonin $5 \mathrm{HT}_{2 a}$ heteromers}

THC binds to $\mathrm{CB}_{1}$ receptors which mediate both its beneficial effects such as analgesia, anxiolytic action and neuroprotection and detrimental effects such as dependence, anxiogenic action or memory impairment (Zou and Kumar, 2018). In addition, cannabis consumption in adolescents is well known to facilitate the appearance of psychosis involving the serotoninergic system (Karila et al., 2014). $\mathrm{CB}_{1}$ receptors are highly expressed in the rat striatum on presynaptic cortical inputs and postsynaptic dendrites of cells located in the patch and matrix compartments (Rodriguez et al., 2001). Since serotoninergic $5 \mathrm{HT}_{2 \mathrm{a}}$ receptors are strongly 
expressed in the PFC and are also present in the striatum (Pazos et al., 1985; Weber and Andrade, 2010), the existence of $\mathrm{CB}_{1}-5 \mathrm{HT}_{2 \mathrm{a}}$ heteromers has been postulated to underlie the functional interaction between the endocannabinoid and serotoninergic systems in this context. $\mathrm{CB}_{1}-5 \mathrm{HT}_{2 \mathrm{a}}$ heteromers were identified in the cortex (somatomotor layers 1,2,3), hippocampus (CA3) and, dorsal striatum by in situ PLA in wild type mice but not in mice deficient for either receptor (Vinals et al., 2015). Infusion (i.c.v.) of the CB1 receptor transmembrane domains TM V or TM VI but not TM VII domain disrupted the PLA signal, indicating that physical association involve TM V and TMVI (Vinals et al., 2015). Importantly, no $\mathrm{CB}_{1}-5 \mathrm{HT}_{2 \mathrm{a}}$ heteromers could be detected in the Nacc (Vinals et al., 2015).

In vivo disruption of the $\mathrm{CB}_{1}-5 \mathrm{HT}_{2 \mathrm{a}}$ physical contact as well as use of $5 \mathrm{HT}_{2 \mathrm{a}}$ knock-out mice revealed that some THC effects such as hypolocomotion, hypothermia, analgesia, anxiogenic effect were exclusively mediated by the $\mathrm{CB}_{1}$ receptor (Vinals et al., 2015). In a protocol of self-administration, the reinforcing properties of the cannabinoid agonist WIN55,212-2 also remained unaffected in $5 \mathrm{HT}_{2 \mathrm{a}}$ knock-out mice. This suggested no involvement of $\mathrm{CB} 1-5 \mathrm{HT}_{2 \mathrm{a}}$ heteromers in agreement with the absence of PLA signal in the Nacc (Vinals et al., 2015). However, following chronic THC administration, symptoms of withdrawal precipitated with the cannabinoid antagonist rimonabant were significantly attenuated in $5 \mathrm{HT}_{2 \mathrm{a}}$ knock-out mice compared to wild type animals pointing to a possible involvement of the $\mathrm{CB}_{1}-5 \mathrm{HT}_{2 \mathrm{a}}$ heteromers in physical dependence (Vinals et al., 2015). In addition, memory impairment (novel object recognition task), anxiolytic effect (elevated plus maze) and increased social interaction induced by acute THC administration were reduced in $5 \mathrm{HT}_{2 \mathrm{a}}$ knock-out mice and/or upon disruption of the physical contact between the two receptors (Vinals et al., 2015). This indicates that $\mathrm{CB}_{1}-5 \mathrm{HT}_{2 \mathrm{a}}$ heteromers modulate these THC dependent effects, in particular, aspects of the THC associated cognitive deficits. 
At the cellular level, $\mathrm{CB} 1-5 \mathrm{HT}_{2 \mathrm{a}}$ heteromerization switched the $5 \mathrm{HT}_{2 \mathrm{a}}$ receptor coupling from the Gaq to the Gai pathway in co-transfected HEK293 cells (Vinals et al., 2015). Co-activation of the receptors in co-transfected HEK293 cells reduced cell signaling by increasing cAMP inhibition and reducing $\beta$-arrestin recruitment without altering ERK1/2 and Akt phosphorylation. (Vinals et al., 2015). Bidirectional cross-antagonism was also observed upon simultaneous administration of an antagonist for one receptor and an agonist for the other on cAMP production, $\beta$-arrestin recruitment, ERK1/2 and Akt phosphorylation (Vinals et al., 2015). Both negative crosstalk and cross-antagonism were reversed upon physical disruption of the $\mathrm{CB}_{1}-5 \mathrm{HT}_{2 \mathrm{a}}$ interaction in co-transfected HEK293 cells (Vinals et al., 2015). Importantly, both were observed in brain regions where $\mathrm{CB}_{1}-5 \mathrm{HT}_{2 \mathrm{a}}$ physical association was observed and were absent in $5 \mathrm{HT}_{2 \mathrm{a}}$ knock-out mice (Vinals et al., 2015).

\subsection{Cannabinoid $\mathrm{CB}_{1}$-adenosine $A_{2 a}$ heteromers}

Adenosine $A_{2 a}$ and $C_{1}$ receptors are expressed in dendritic spines of striatopallidal GABAergic neurons and their close physical proximity was established by coimmunoprecipitation from rat striatal membranes (Carriba et al., 2007; Ferreira et al., 2015). Further data in favor of heteromerization were collected in co-transfected cells by BRET experiments (Carriba et al., 2007). In SHSY5Y neuroblastoma that endogenously co-express the two receptors, efficient $\mathrm{CB}_{1}$ receptor coupling to inhibitory $\mathrm{G}$ protein requires simultaneous activation of $\mathrm{A}_{2 \mathrm{a}}$ receptors and is abolished in the presence of an $\mathrm{A}_{2 \mathrm{a}}$ selective antagonist indicative of cross-antagonism (Carriba et al., 2007). Accordingly, blocking $\mathrm{A}_{2 \mathrm{a}}$ receptors with the $\mathrm{A}_{2 \mathrm{a}}$ antagonist MSX-3 counteracted the decrease in locomotor activity promoted by intrastriatal bilateral administration of the $\mathrm{CB}_{1}$ agonist WIN55212-2 (Carriba et al., 2007). In addition, decreased conditioned place preference to THC was observed in $\mathrm{A}_{2 \mathrm{a}}$ receptor knockout mice supporting a role for $\mathrm{CB}_{1}-\mathrm{A}_{2 \mathrm{a}}$ heteromers (Soria et al., 2004). 
Functional interaction of $\mathrm{A}_{2 \mathrm{a}}$ and $\mathrm{CB}_{1}$ receptors in presynaptic corticostriatal synapses was also postulated using radioligand binding in nerve terminal membranes, glutamate release assay in acutely isolated nerve terminals and paired-pulse ratio measurements in isolated monosynaptic contacts in corticostriatal slices (Ferreira et al., 2015). However, in this case, $\mathrm{A}_{2 \mathrm{a}}$ receptor activation dampened $\mathrm{CB}_{1}$ receptor function and $\mathrm{CB}_{1}$-mediated inhibition of corticostriatal glutamatergic inputs (Ferreira et al., 2015). These results suggest that activation of the $\mathrm{A}_{2 \mathrm{a}}$ receptor would have opposite effects on $\mathrm{CB}_{1}$ receptor signaling depending on the pre- or post-synaptic localization of the $\mathrm{CB}_{1}-\mathrm{A}_{2 \mathrm{a}}$ heteromer.

\section{Class A-Class A Heteromers with potential role in SUD}

Here, we review heteromers for which impact on cellular mechanisms relevant to SUD have been evidenced, although no direct behavioral outcome has been reported yet.

\subsection{Mu opioid-cannabinoid $\mathrm{CB}_{1}$ heteromers}

Both mu opioid and cannabinoid $\mathrm{CB}_{1}$ receptors are primary targets of drugs of abuse and widely expressed throughout the brain (Erbs et al., 2015; Nguyen et al., 2010). Heteromerization between these two receptors is thus bound to strongly alter drug effects. BRET measurements in co-transfected HEK293 cells established the ability of the two receptors to physically interact and ultrastructural analysis in the rat caudate putamen revealed discrete co-localization of the two receptors in MSNs (Rios et al., 2006). The presence of $\mathrm{CB}_{1}$ receptors in mu enriched patches suggested that the two receptors could modulate the output of these GABAergic neurons (Rodriguez et al., 2001). This may account for the similar impact of the two receptors on motor activity.

Interestingly, THC was reported to allosterically decrease opiate binding at the mu opioid receptor in rat brain membranes (Vaysse et al., 1987). In addition, simultaneous coactivation of the receptors in SK-N-SH neuroblastoma cell line or rat striatal membranes decreased G protein-dependent signaling (Rios et al., 2006). This bidirectional negative 
crosstalk was associated with decreased activation of the G protein-Src-STAT3 pathway in mu-transfected Neuro $_{2 \mathrm{a}}$ cells and a negative impact on neuritogenesis (Rios et al., 2006) which may contribute to drug related neuroplasticity.

Social play has a strong rewarding value and is modulated by neurotransmitters involved in reward and motivation. Accordingly, increased activity of the opioid, endocannabinoid or dopamine receptors in the Nacc enhanced social play in rodents ((Manduca et al., 2016) and refs therein). Systemic injection of the endocannabinoid 2-arachidonoyl (2AG) hydrolysis inhibitor JZL184 increased social play behavior in adolescent rodents (Manduca et al., 2016). This effect was blocked by infusion in the NAcc of the mu antagonist CTAP and was absent in mu knock-out mice (Manduca et al., 2016). Reciprocally, systemic injection of the mu opioid agonist morphine increased social play and was abolished by the $\mathrm{CB}_{1}$ antagonist SR1417-16 or in $\mathrm{CB}_{1}$ knock-out mice (Manduca et al., 2016). Whole cell recordings of miniature excitatory postsynaptic currents revealed functional presynaptic interaction between $\mathrm{CB}_{1}$ and $\mathrm{mu}$ opioid receptors. Indeed, $\mathrm{CB}_{1}$ antagonists reduced the inhibition exerted by the mu opioid receptor on excitatory transmission influencing Nacc neurons and vice versa (Manduca et al., 2016). Altogether, these data revealed bidirectional cross-antagonism taking place at mu- $\mathrm{CB}_{1}$ heteromers and strongly suggest that functional mu$\mathrm{CB}_{1}$ heteromers in the Nacc can modulate the rewarding properties of drugs of abuse.

\subsection{Cannabinoid $\mathrm{CB}_{1}-\mathrm{CB}_{2}$ heteromers}

Cannabinoid $\mathrm{CB}_{1}$ receptors are the primary molecular target for $\mathrm{THC}$. $\mathrm{CB}_{1}$ receptors are widely distributed throughout the brain (Nguyen et al., 2010). In the striatum, they are often located presynaptically on GABAergic terminals of interneurons or collaterals from MSNs (Matyas et al., 2006) but they are also present in glutamatergic terminals (Huang et al., 2001).

Striatal postsynaptic $\mathrm{CB}_{1}$ receptors are located in the somatodendritic compartment of 
dynorphin and enkephalin positive MSNs (Callen et al., 2012; Martin et al., 2008) and references therein). $\mathrm{CB}_{2}$ receptors are mostly expressed outside the CNS but evidence is accumulating for their presence in the brain where they are mostly postsynaptic ((Callen et al., 2012) and references therein). Physical proximity indicative of heteromer formation with the $\mathrm{CB}_{1}$ receptor was reported using in situ PLA in the rat striatum (Callen et al., 2012).

As described for mu opioid- $\mathrm{CB}_{1}$ heteromers, $\mathrm{CB}_{1}-\mathrm{CB}_{2}$ co-activation resulted in a negative cross-talk on the $\mathrm{Akt} / \mathrm{PKB}$ signaling and $\mathrm{CB}_{1}-\mathrm{CB}_{2}$ cross antagonism decreased ERK1/2 and Akt/PKB phosphorylation, thereby reducing neurite outgrowth (Callen et al., 2012). Activation of the striatal microglia increased $\mathrm{CB}_{1}-\mathrm{CB}_{2}$ heteromerization. Moreover, microglial activation changed the negative crosstalk on $\mathrm{CB}_{1}-\mathrm{CB}_{2}$ signaling observed in resting cells upon co-stimulation by the $\mathrm{CB}_{1}$ agonist $\mathrm{ACEA}$ and the $\mathrm{CB}_{2}$ agonist JWH133 into a positive cross-talk in activated cells (Navarro et al., 2018a). This is in line with a study indicating that activation of the endocannabinoid system, and more specifically of the $\mathrm{CB}_{2}$ receptor, before methamphetamine administration reduced the neurotoxicity of the drug (Nader et al., 2014). Also, cocaine increased $\mathrm{CB}_{1}$ and decreased $\mathrm{CB}_{2}$ expression in the PFC and hippocampus of adolescent rats (Garcia-Cabrerizo and Garcia-Fuster, 2016). Although $\mathrm{CB}_{1}$ $\mathrm{CB}_{2}$ heteromers have not been evidenced in the cortex so far, one can postulate that cocaine could prevent their neuroprotective effect by decreasing their expression, which may contribute to the addiction vulnerability observed in adolescents (Bagot et al., 2015). $\mathrm{CB}_{1}-\mathrm{CB}_{2}$ heteromers may therefore represent a therapeutic target to reduce neuroinflammation that develops in SUD (Karoly et al., 2015).

\subsection{Dopamine $D_{3} / D_{3 n f}$ heteromers}

Several pieces of evidence link the dopamine $\mathrm{D}_{3}$ receptor to SUD. First, expression of dopamine $\mathrm{D}_{3}$ receptors is increased in several brain areas from cocaine abusers, 
metamphetamine users and alcohol dependent patients (for reviews (Prieto, 2017; Sokoloff and Le Foll, 2017). Second, the Ser9Gly polymorphism known to enhance ERK signaling and to be responsible for essential tremor has also been linked to early onset of heroin dependence in Han Chinese subjects (Kuo et al., 2014). Third, $\mathrm{D}_{3}$ receptors are involved in locomotor responses to spatial novelty and psychostimulants (Pritchard et al., 2006). Indeed, $\mathrm{D}_{3}$ receptors modulate glutamatergic pathways from the PFC to subcortical areas, either directly by interacting with N-methyl-D-aspartate (NMDA) receptors in the Nacc, or indirectly by controlling dopamine release from VTA neurons. Because $\mathrm{D}_{3}$ receptors are associated with the ventral forebrain mesolimbic system, they influence reward, emotions and motivation but also affects drug seeking and relapse, particularly related with drug associated cues (for a recent review (Sokoloff and Le Foll, 2017).

Co-immunoprecipitation in rat brain revealed physical proximity between the $\mathrm{D}_{3}$ and truncated $\mathrm{D}_{3 \mathrm{nf}}$ receptors (Nimchinsky et al., 1997). In baculovirus infected $\mathrm{Sf} 9$ cells, $\mathrm{D}_{3}-\mathrm{D}_{3 \mathrm{nf}}$ heteromerization abolished $\mathrm{D}_{3}$ activity by inhibiting ligand binding to the receptor (Elmhurst et al., 2000). In co-transfected HEK 293 cells, $\mathrm{D}_{3}-\mathrm{D}_{3 \mathrm{nf}}$ association led to predominant cytoplasmic mislocalization of the $\mathrm{D}_{3}$ receptor (Karpa et al., 2000). This inactive variant seems thus to play a regulatory role and to reduce functional $\mathrm{D}_{3}$ receptor availability. In the high responder/low responder model, individual differences in the locomotor responses to an inescapable, novel spatial environment predict individual differences in the locomotor and reinforcing effects of psychostimulants (Pritchard et al., 2006). In this model, the $\mathrm{D}_{3} / \mathrm{D}_{3 \mathrm{nf}}$ ratio was decreased in the PFC, SN and VTA of rat high responder to novelty compared to low responder but remained unaffected in the Nacc (Pritchard et al., 2006). Accordingly, the $\mathrm{D}_{3} / \mathrm{D}_{3 \mathrm{nf}}$ ratio has been proposed to play a role in cocaine sensitization and addiction (Richtand, 2006). Surprisingly, in a protocol of sensitization to nicotine involving three exposures to the 
drug, the $D_{3} / D_{3 n f}$ ratio was increased in the Nacc of adolescent and adult rats suggesting a potential increase in receptor $\mathrm{D}_{3}$ receptor availability (Smith et al., 2015).

\subsection{Dopamine $D_{1}-D_{3}$ heteromers}

$\mathrm{D}_{1}$ and $\mathrm{D}_{3}$ receptors were co-immunoprecipitated from rat brain membranes (Fiorentini et al., 2008). Co-activation of the receptors potentiated the stimulatory effect of dopamine on cAMP and led to co-internalization of the two receptors in co-transfected HEK 293 cells (Fiorentini et al., 2008). Since agonist stimulation of $\mathrm{D}_{3}$ receptors did not promote $\mathrm{D}_{3}$ receptor internalization when expressed alone, this suggested a switch towards $D_{1}$ receptor specific desensitization mechanisms (Fiorentini et al., 2008). In striatal membranes, enhanced agonist affinity was observed at the $\mathrm{D}_{1}$ receptor upon $\mathrm{D}_{3}$ receptor co-activation (Marcellino et al., 2008). In reserpinized mice, a model to study the function of postsynaptic striatal dopamine receptors without the influence of endogenous dopamine, $\mathrm{D}_{3}$ receptor activation potentiated $\mathrm{D}_{1}$ dependent locomotor activity (Marcellino et al., 2008). This positive cross-talk was counteracted by a $D_{3}$ selective antagonist and abolished in $\mathrm{D}_{3}$ knock-out mice (Marcellino et al., 2008). $\mathrm{D}_{1}-\mathrm{D}_{3}$ heteromers by modulating the direct striatonigral pathway may therefore contribute to psychostimulant locomotor sensitization.

\subsection{Dopamine $D_{1}$-histamine $\mathrm{H}_{3}$-sigma1 heteromers}

The histamine $\mathrm{H}_{3}$ receptor is abundantly expressed in the striatum and mostly located post-synaptically in both $\mathrm{D}_{1}$ and $\mathrm{D}_{2}$ expressing MSNs. The interaction of the histamine $\mathrm{H}_{3}$ receptor with the dopaminergic system and its implication in alcohol or psychostimulant abuse is well established (Bakker et al., 2006; Ellenbroek, 2013; Panula and Nuutinen, 2011). Physical proximity of histamine $\mathrm{H}_{3}$ and dopamine $\mathrm{D}_{1}$ receptors was verified by coimmunoprecipitation experiments in rat (Moreno et al., 2011a) and mouse (Moreno et al., 
2014) striatal membranes. It was further confirmed in the mouse striatum using PLA (Moreno et al., 2014).

At the cellular level, the $\mathrm{D}_{1}$ receptor couples to the Gas subunit and increases cAMP production. However, in neuroblastoma cells co-transfected with $\mathrm{D}_{1}$ and $\mathrm{H}_{3}$ receptors, $\mathrm{D}_{1}$ agonists led to reduced forskolin induced cAMP suggesting that the $\mathrm{D}_{1}$ receptor now activated the inhibitory Gai/o pathway through its association with the $\mathrm{H}_{3}$ receptor (Ferrada et al., 2009). Co-transfection of $\mathrm{D}_{1}$ and $\mathrm{H}_{3}$ receptors led to ERK1/2 phosphorylation upon activation by $\mathrm{H}_{3}$ agonists which was not observed when the $\mathrm{H}_{3}$ receptor was expressed alone (Ferrada et al., 2009). Accordingly, the ability of $\mathrm{H}_{3}$ receptors to stimulate ERK $1 / 2$ phosphorylation was not observed in $\mathrm{D}_{1}$ receptor knock-out mice (Moreno et al., 2011a) supporting a role for $\mathrm{D}_{1}-\mathrm{H}_{3}$ heteromerization. Moreover, $D_{1}$ receptor expression was decreased and no ERK1/2 phosphorylation following $\mathrm{D}_{1}$ agonist activation was observed in the striatum of $\mathrm{H}_{3}$ receptor knock-out mice suggesting that the presence of the $\mathrm{H} 3$ receptor is required for the $\mathrm{D} 1$ receptor to be fully functional (Kononoff Vanhanen et al., 2016). However, $\mathrm{H}_{3}$ receptor activation inhibited $\mathrm{D}_{1}$ dependent ERK1/2 phosphorylation in striatal membrane revealing a negative crosstalk on D1 signaling when the two receptors were simultaneously activated (Moreno et al., 2014).

Antagonists for either receptor blocked ERK1/2 phosphorylation in striatal membranes or neuroblastoma cells co-transfected with $\mathrm{D}_{1}$ and $\mathrm{H}_{3}$ receptors indicating that $\mathrm{D}_{1}-\mathrm{H}_{3}$ heteromerization was also associated with bidirectional cross-antagonism (Ferrada et al., 2009; Moreno et al., 2014).

Acute cocaine application on organotypic cultures from mouse striatum inhibited $\mathrm{D}_{1}$ $\mathrm{H}_{3}$ bidirectional cross antagonism and reduced the negative cross-talk exerted by $\mathrm{H}_{3}$ receptor activation on $\mathrm{D}_{1}$ receptor signaling (Moreno et al., 2014). A similar impact on $\mathrm{D}_{1}-\mathrm{H}_{3}$ heteromer signaling was observed following chronic exposure to cocaine using striatal slices from rats 
that self-administered the drug for 6-11 weeks (Moreno et al., 2014). Since none of the receptors has affinity for cocaine, association with the sigmal receptor that efficiently binds this psychostimulant was postulated (Matsumoto et al., 2002). Co-immunoprecipitation and in situ PLA experiments both confirmed the physical proximity between sigmal and $\mathrm{D}_{1}$ or $\mathrm{H}_{3}$ receptors (Moreno et al., 2014). Accordingly, all tested effects of cocaine on $\mathrm{D}_{1}-\mathrm{H}_{3}$ heteromer signaling were abolished in striatal organotypic cultures from mice deficient for the sigmal receptor (Moreno et al., 2014). Since drugs of abuse all increase extracellular dopamine level which initiates oxidative stress and neurotoxicity (Cunha-Oliveira et al., 2008), the authors explored the functional role of $\mathrm{D}_{1}-\mathrm{H}_{3}$ heteromers on striatal neuron survival. Activation of $\mathrm{D}_{1}$ receptors induced cell death that was counteracted by activation of the $\mathrm{H}_{3}$ receptor or by coadministration of $\mathrm{D}_{1}$ or $\mathrm{H}_{3}$ selective antagonists (Moreno et al., 2014). Both effects were absent following exposure of the organotypic slices to cocaine (Moreno et al., 2014). Involvement of the sigmal receptor in the cocaine effects on neuronal cell death was then investigated. Pretreatment with a sigmal agonist mimicked cocaine effects whereas pretreatment with a sigmal antagonist abolished blockade of both $\mathrm{D}_{1}-\mathrm{H}_{3}$ cross-antagonism and negative crosstalk on $\mathrm{D}_{1}$ signaling by cocaine (Moreno et al., 2014). Altogether, these data point to $\mathrm{D}_{1}-\mathrm{H}_{3}$-sigmal heterocomplexes as potential target for the treatment of cocaine abuse.

\subsection{Dopamine $\mathrm{D}_{2}$-histamine $\mathrm{H}_{3}$ heteromers}

The histamine $\mathrm{H}_{3}$ receptor was co-immunoprecipitated with the dopamine $\mathrm{D}_{2}$ receptor in rat striatal membranes establishing physical proximity between them (Moreno et al., 2011a). In mice deficient for the $\mathrm{H}_{3}$ receptor, $\mathrm{D}_{2}$ agonist induced locomotion was altered and $\mathrm{D}_{2}$ agonists did not promote ERK1/2 phosphorylation in the striatum (Kononoff Vanhanen et al., 2016) supporting functional interaction in $\mathrm{D}_{2}-\mathrm{H}_{3}$ heteromers. 
Since $\mathrm{D}_{2}$ receptors can also form heteromers with sigmal (see section 4.2) or $\mathrm{D}_{1}$ (see section 4.3) receptors, larger complexes associating $\mathrm{H}_{3}-\mathrm{D}_{2}$-sigmal receptors or $\mathrm{H}_{3}-\mathrm{D}_{2}-\mathrm{D}_{1}$ sigmal receptors may exist whose modulatory role of the striatal GABAergic signaling remains to be elucidated.

\subsection{Adenosine $A_{1}$-adenosine $A_{2 a}$ heteromers}

The Gai/o coupled adenosine $A_{1}$ and Gas coupled $A_{2 a}$ receptors co-localize in glutamatergic terminals in the rat striatum as indicated by co-immunoprecipitation and electron microscopy (Ciruela et al., 2006). Upon $\mathrm{A}_{1}-\mathrm{A}_{2 \mathrm{a}}$ heteromerization, activation of the $\mathrm{A}_{2 \mathrm{a}}$ receptor reduces the affinity and efficacy of $\mathrm{A}_{1}$ agonists consistent with a negative cross-talk on $\mathrm{A}_{1}$ signaling (Ciruela et al., 2006). $A_{1}$ receptors have higher affinity for adenosine than $A_{2 A}$ receptors. Accordingly, at low adenosine concentrations, preferred activation of $\mathrm{A}_{1}$ receptors will inhibit glutamate release whereas, at higher concentrations, adenosine will also bind to $\mathrm{A}_{2 \mathrm{a}}$ receptors and facilitate glutamate release by inhibiting $A_{1}$ signaling through $A_{2 a}-A_{1}$ heteromers. Caffeine is a non-selective antagonist of $\mathrm{A}_{1}$ and $\mathrm{A}_{2 \mathrm{a}}$ receptors with arousing and psychomotor effects similar to prototypical psychostimulants such as cocaine or amphetamines. Caffeine has higher affinity for $\mathrm{A}_{2 \mathrm{a}}$ receptors than for $\mathrm{A}_{1}$ receptors in transfected cells expressing only one receptor type but $A_{2 a}$ affinity for caffeine decreases upon $A_{2 a}-A_{1}$ heteromerization (Ciruela et al., 2006). Acute caffeine that results in low adenosine concentration would block $A_{1}$ receptors and enhance glutamatergic release. On the contrary, chronic caffeine would result in higher adenosine concentrations through inhibition of the ENT1 transporter and would inhibit glutamatergic release through $\mathrm{A}_{1}-\mathrm{A}_{2 \mathrm{a}}$ heteromers (Ciruela et al., 2006). $\mathrm{A}_{1}-\mathrm{A}_{2 \mathrm{a}}$ heteromers can therefore contribute to modulate striatal activity and may also associate with $\mathrm{D}_{2}$ and sigmal receptors to form larger heterocomplexes. 


\subsection{Class A-class A heteromers with unexplored role in SUD}

In vivo physical proximity has been reported for several additional class A receptor pairs involving at least one of the receptors playing a role in SUD. This includes cannabinoid $\mathrm{CB}_{1}$ delta opioid receptors (cortex, striatum) (Bushlin et al., 2012), dopamine $\mathrm{D}_{2}$-somatostatin sst 2 receptors (primary striatal cultures) (Baragli et al., 2007), adenosine $\mathrm{A}_{2 \mathrm{a}}$-purinergic $\mathrm{P}_{2} \mathrm{Y}_{1}$ receptors (cortex) (Yoshioka et al., 2002), mu opioid-adrenergic $\mathrm{A}_{2 \mathrm{a}}$ receptors (primary hippocampal cultures, nucleus of the solitary tract) (Jordan et al., 2003; Sun et al., 2015), histamine $\mathrm{H} 3$ receptor- non-functional histamine $\mathrm{H} 3$ truncated splice variant (cortex, caudate putamen, hippocampus) (Bakker et al., 2006). The functional relevance of these heteromers in the context of SUD remains to be established but they could enrich the actual possibilities to modulate the various aspects of drug addiction.

Also, additional heteromers have been described that do not involve receptors for drugs of abuse but modulate neuronal and/or glial functions such as those involving association of opioid and chemokine receptors (reviewed in (Melik Parsadaniantz et al., 2015) (Kramp et al., 2011)) or heteromerization of serotonin receptors (reviewed in (Gaitonde and GonzalezMaeso, 2017)). They are key players in neuroinflammation, nociception or depression, and may therefore contribute to the expression of symptoms associated with SUD.

\section{Class A-class C heteromers and SUD}

Much less is known to date on the functional consequences of heteromerization between these class A and class C GPCRs in the context of drug addiction, However, the wide distribution of $\mathrm{GABA}_{\mathrm{B}}$ receptors (Charles et al., 2001), the presence of $\mathrm{mGlu}_{5}$ receptors in the cortex, striatum and Nacc and the high cortical expression of $\mathrm{mGlu}_{2}$ subunits (Ferraguti and Shigemoto, 2006) designate them as potential modulators of neuronal activity in the context of SUD and associated psychosis. 


\subsection{Serotonin $5 \mathrm{HT}_{2 a}$-metabotropic glutamate $\mathrm{mGlu_{2 }}$ heteromers}

The implication of the serotoninergic system in mood, anxiodepressive disorders and other psychosis such as schizophrenia is well established. This neuromodulatory system is also the target of hallucinogenic substances isolated from mushrooms (psilocybin, mescaline) or of synthetic compounds such as LSD, which can also be abused leading to tolerance and psychological dependence (Das et al., 2016). These hallucinogenic drugs bind to $5 \mathrm{HT}_{2 \mathrm{a}}$ receptors but not only recruit the canonical $5 \mathrm{HT}_{2 \mathrm{a}}$ dependent $\mathrm{G} \alpha \mathrm{q} / 11$ pathway but also stimulate Gai/o signaling (Gonzalez-Maeso et al., 2008). Therefore, they modify the Gai/Gaq coupling and signaling balance in favor of the inhibitory signaling cascade.

Serotonin $5 \mathrm{HT}_{2 \mathrm{a}}$ and metabotropic glutamate $\mathrm{mGlu}_{2}$ receptors were coimmunoprecipitated in mouse (Fribourg et al., 2011) and human cortical membranes (Gonzalez-Maeso et al., 2008). The two receptors were also co-localized near synaptic junctions in mouse cortical neurons (Moreno et al., 2012). Studies using chimeras containing various ratios of $\mathrm{mGlu}_{2}$ receptor showed that the $\mathrm{mGlu}_{2}$ transmembrane domains TM IV and $\mathrm{V}$ are mandatory for association with $5 \mathrm{HT}_{2 \mathrm{a}}$ receptors with three alanine residues (A677, A681, A685) at the TM IV intracellular end essential for heteromerization (Moreno et al., 2012).

In oocytes from Xenopus laevis co-expressing $5 \mathrm{HT}_{2 \mathrm{a}}$ and $\mathrm{mGlu}_{2}$ receptors, $5 \mathrm{HT}_{2 \mathrm{a}}$ mediated Gaq/11 activation in response to serotonin was decreased by $50 \%$ and $\mathrm{mGlu}_{2}$ mediated Gai/o signaling in response to glutamate was enhanced by $200 \%$. Activation of $5 \mathrm{HT}_{2 \mathrm{a}}-\mathrm{mGlu}_{2}$ heteromers by endogenous ligands therefore favored Gai over Gaq signaling. This shift was specific to the $5 \mathrm{HT}_{2 \mathrm{a}}-\mathrm{mGlu}_{2}$ receptor pair since it was not observed upon coexpression of the $5 \mathrm{HT}_{2 \mathrm{a}}$ receptor with the non-interacting $\mathrm{mGlu}_{3}$ receptor (Fribourg et al., 2011). In addition, occupancy of one of the receptors by an agonist, an antagonist or an inverse

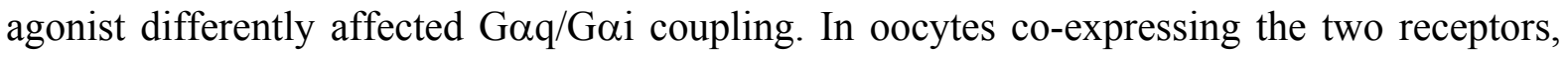
agonists favored signaling through their cognate receptor and decreased signaling though the 
associated receptor indicative of bidirectional negative cross-talk. In contrast, positive allosteric modulation was observed with inverse agonists. Indeed, inverse agonists inhibited signaling through their cognate receptor and enhanced signaling through the associated receptor (Fribourg et al., 2011). Similar increases in signaling of the partner receptor by inverse agonist was also observed in cortical neurons in vivo (Fribourg et al., 2011). Accordingly, activation of the mGlu $_{2}$ receptor by the agonist LY379268 suppressed the Gai dependent hallucinogenic effect of the $5 \mathrm{HT}_{2 \mathrm{a}}$ agonist DOI in membranes from the mouse PFC (GonzalezMaeso et al., 2008) and the effects of the inverse agonist LY341495 were significantly attenuated in $5 \mathrm{HT}_{2 \mathrm{a}}$ knock-out mice (Fribourg et al., 2011; Gonzalez-Maeso et al., 2008). The causal link between $5 \mathrm{HT}_{2 \mathrm{a}}-\mathrm{mGlu}_{2}$ physical association and the head twitch behavioral response to hallucinogens was then conclusively established. In mice deficient for the $\mathrm{mGlu}_{2}$ receptor, administration of the $5 \mathrm{HT}_{2 \mathrm{a}}$ agonist DOI did not induce head twitching revealing the essential role of this Gai coupled receptor (Moreno et al., 2011b). Rescuing mGlu $_{2}$ receptor expression in the mouse frontal cortex upon herpes viral infection restored the behavioral response (Moreno et al., 2012). However, no behavioral response was observed following re-expression of a $\mathrm{mGlu}_{2}$ receptor missing the three alanine residues in the transmembrane domain TM IV that are essential for physical association with the $5 \mathrm{HT}_{2 \mathrm{a}}$ (Moreno et al., 2012), confirming that $5 \mathrm{HT}_{2 \mathrm{a}}-\mathrm{mGlu}_{2}$ heteromers mediate the specific response to hallucinogens.

\subsection{Adenosine $A_{2 a^{-}}$metabotropic glutamatergic mGlu ${ }_{5}$ heteromers}

Physical proximity of adenosine $\mathrm{A}_{2 \mathrm{a}}$ and metabotropic glutamate $\mathrm{mGlu}_{5}$ receptors was first determined by co-immunoprecipitation using rat striatal membranes (Ferre et al., 2002). Detection of $\mathrm{A}_{2 \mathrm{a}}-\mathrm{mGlu}_{5}$ heteromers by in situ PLA in mice revealed homogenous distribution throughout the striatum that was not affected in a protocol of habit formation (random interval training) or goal directed behavior (random ratio training) (He et al., 2016). The same approach 
uncovered increased $\mathrm{A}_{2 \mathrm{a}}-\mathrm{mGlu}_{5}$ heteromers in the Nacc shell following cocaine selfadministration (Borroto-Escuela et al., 2017). Co-injection (i.c.v.) of the $\mathrm{A}_{2 \mathrm{a}}$ agonist CGS21680 and the mGlu $_{5}$ agonist CHPG led to increased c-Fos expression in the Nacc but not in the caudate putamen or in the cingulate cortex (Ferre et al., 2002). Dual-probe microdialysis in freely moving rats revealed that co-administration of the $\mathrm{A}_{2 \mathrm{a}}$ agonist CGS21680 and the $\mathrm{mGlu}_{5}$ agonist $\mathrm{CHPG}$ led to synergistic effect and negatively modulated dopamine $\mathrm{D}_{2}$ signaling thereby enhancing glutamate and GABAergic extracellular levels in the globus pallidus (Beggiato et al., 2016). This suggests that $\mathrm{A}_{2 \mathrm{a}}-\mathrm{mGlu}_{5}$ heteromers may serve to overcome the strong tonic inhibitory effect of dopamine on striatal $\mathrm{A}_{2 \mathrm{a}}$ function and may contribute to modulate locomotor activation and sensitization by psychostimulants. In addition, increased levels of heteromerization between $\mathrm{A}_{2 \mathrm{a}}-\mathrm{D}_{2}, \mathrm{D}_{2}$-sigma $1, \mathrm{~A}_{2 \mathrm{a}}-\mathrm{mGlu}_{5}$ receptors detected by in situ PLA in the NAcc shell (Borroto-Escuela et al., 2017) suggest that these four receptors may associate in larger signaling platforms to modulate the striatopallidal activity.

\subsection{Muscarinic $M_{2}$-metabotropic $G A B A_{B 2}$ heteromers}

Co-expression of the $\mathrm{GABA}_{\mathrm{B} 2}$ but not the $\mathrm{GABA}_{\mathrm{B} 1}$ subunit in neuronal PC12 cells rescued surface expression of the muscarinic $\mathrm{M}_{2}$ receptor and functional coupling to GIRK channels upon chronic stimulation with acetylcholine (Boyer et al., 2009). Mutagenesis combined with FRET established that the interaction took place between the proximal Cterminal domain of $\mathrm{GABA}_{\mathrm{B} 2}$ (P741 to V776) and the last 23 amino acids of the $\mathrm{C}$-terminal domain of the muscarinic $\mathrm{M}_{2}$ receptor. Importantly, the interaction site on the $\mathrm{GABA}_{\mathrm{B} 2}$ receptor was distinct from the coiled-coil domain responsible for the obligatory $\mathrm{GABA}_{\mathrm{B} 1} / \mathrm{GABA}_{\mathrm{B} 2}$ dimerization (Boyer et al., 2009). Therefore, it is unknown whether muscarinic $\mathrm{M}_{2}$ receptors interact with the $\mathrm{GABA}_{\mathrm{B} 2}$ receptor only or rather with the functional dimeric $\mathrm{GABA}_{\mathrm{B} 1 / 2}$ receptor. Co-immunoprecipitation from rat cortical membrane of $\mathrm{GABA}_{\mathrm{B} 2}$ 
subunit together with the muscarinic $\mathrm{M}_{2}$ receptor confirmed in vivo proximity (Boyer et al., 2009) and suggested that the heteromer may play a role in drug addiction by modulating the

endogenous acetylcholine tone at presynaptic level. A possible outcome would be a contribution of these heteromers to the discriminative stimulus properties of cocaine (Joseph and Thomsen, 2017).

\section{Class A GPCR-ion channels heteromers with potential role in SUD}

Physical association involving class A GPCRs is not restricted to interactions with another GPCR but can also involve ion channels, which would account for the growing complexity of interactions already identified. This emphasizes the need to adapt our current view of a functional unit to encompass broader associations taking place within a cluster of proteins of more than two types.

\subsection{Dopamine receptor-Voltage-gated $\mathrm{Ca}^{2+}$ channel heteromers}

Physical proximity between dopamine $\mathrm{D}_{2}$ receptors and voltage gated $\mathrm{N}$-type $\mathrm{Ca}^{2+}$ channels was identified by co-immunoprecipitation in the rat striatum (Kisilevsky and Zamponi, 2008) where the Gai/o coupled $\mathrm{D}_{2}$ receptors exert robust voltage dependent and independent inhibition of N-type channels. Importantly, voltage independent $\mathrm{D}_{2}$ inhibition appeared to be mediated through $\mathrm{D}_{2}-\mathrm{N}$-type channel heteromerization since obliterated upon disruption of physical association. In addition, $\mathrm{D}_{2}-\mathrm{N}$-type channel association increased cell surface expression of the channel and promoted $\mathrm{D}_{2}$ agonist-induced internalization in cotransfected HEK 293 cells (Kisilevsky and Zamponi, 2008).

Dopamine $\mathrm{D}_{1}$ receptors couple to Gas and enhance L-type $\mathrm{Ca}^{2+}$ channels through voltage independent pathways involving PKA activation. In the rat PFC, however, $\mathrm{D}_{1}$ receptors co-immunoprecipitated with $\mathrm{N}$-type $\mathrm{Ca}^{2+}$ channels and inhibited their activity by a combination

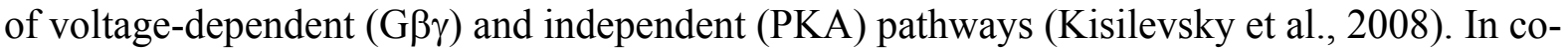


transfected HEK 293 cells, $\mathrm{D}_{1}$-N-type channel heteromer formation increased surface expression of the channel and promoted co-internalization following $\mathrm{D}_{1}$ activation (Kisilevsky et al., 2008). In primary cortical neurons, $D_{1}$ receptors regulated channel distribution in dendritic compartments. Importantly, $\mathrm{D}_{1}$ regulation of N-type channel activity appeared selective to the PFC and was not observed in the striatum where no $D_{1}$-channel physical proximity could be detected. The reason for this region specificity, however, remains unknown. Given the neuroplasticity induced by drugs of abuse that involve increased $D_{1}$ signaling (Volkow and Morales, 2015), this type of interaction provides a mechanism by which D1 could contribute to dopaminergic inhibition of N-type channel activity during back propagating action potentials and hence could participate in the control exerted by the PFC on the striatum. The functional contribution of these heteromers in the context of SUD remains however to be established.

\subsection{Opioid like receptor ORL1-Voltage-gated $\mathrm{Ca}^{2+}$ channel heteromers}

Physical proximity between the Gai/o coupled opioid ORL1 receptor and the voltage gated $\mathrm{N}$-type $\mathrm{Ca}^{2+}$ channels was established in the rat brain by co-immunoprecipitation (Beedle et al., 2004). Similar to the inhibitory control exerted by $\mathrm{D}_{1}$ or $\mathrm{D}_{2}$ receptors in the brain, N-type channel association with ORL1 resulted in a tonic inhibition of the channels in DRGs. The latter was attributed to ORL1 constitutive activity. The agonist nociceptin also led to G protein dependent inhibition of N-type channels and promoted receptor-channel co-internalization in the DRG, both mechanisms contributing to reduce $\mathrm{Ca}^{2+}$ entry (Altier et al., 2006). Regulation of N-type channel surface expression was also observed upon co-expression with $\mathrm{D}_{1}$ or $\mathrm{D}_{2}$ dopamine receptors (Kisilevsky et al., 2008; Kisilevsky and Zamponi, 2008), and may reflect a general mechanism by which N-type channel expression and activity are regulated. ORL1 and its endogenous ligand nociceptin/orphanin-FQ (N/OFQ) are widely distributed throughout 
the brain and are present in areas that critically mediate motivated and addictive behaviors such as the central nucleus of the amygdala, the bed nucleus of the stria terminalis, the medial PFC, the VTA, or the Nacc (Ozawa et al., 2015). Activation of ORL1 regulates drug reward and drug-seeking behaviors associated with opiates, psychostimulants or ethanol (reviewed in (Witkin et al., 2014)). With respect to ethanol-mediated behaviors, ORL1 agonists attenuate conditioned place preference, ethanol self-administration, and ethanol-seeking behaviors in rat lines genetically-selected for high alcohol preference presumably through decreased dopamine

release (reviewed in (Witkin et al., 2014)). In addition, mu opioid receptors can associate with ORL1 as shown by co-immunoprecipitation in the DRGs where activation of the mu opioid receptor led to co-internalization of the N-type channel. This was not observed when the ORL 1 receptor was absent (Evans et al., 2010) and therefore indicates formation of larger heterocomplexes. Because of the broad overlap in the distributions of mu and ORL1 receptors (Ozawa et al., 2015) and the broad expression of N-type channels in the brain (Kamp et al., 2012), such complexes are likely to form at supraspinal levels and may therefore participate to the response to drugs of abuse, especially when considering that the mu opioid receptor acts as a gateway for many of these (Contet et al., 2004).

\subsection{Class $A$ receptor-NMDA channel heteromers}

Co-immunoprecipitation experiments uncovered physical proximity between the dopamine $\mathrm{D}_{1}$ and the $\mathrm{NR}_{1}$ subunit of NMDA channels in the rat hippocampus (Pei et al., 2004) and striatal post-synaptic membrane preparations (Fiorentini et al., 2003). Interaction between the two proteins takes place in the ER and increases $D_{1}$ receptor surface expression (Fiorentini et al., 2003) through contacts involving their C-termini (Pei et al., 2004). In addition, $\mathrm{D}_{1}$ heteromerization with $\mathrm{NR}_{1}$ enhanced $\mathrm{D}_{1}$ signaling in primary hippocampal neurons (Pei et al., 
2004) and abolished its internalization upon agonist activation in co-transfected HEK293 cells (Fiorentini et al., 2003)

Physical proximity was also identified by co-immunoprecipitation in the mouse periaqueductal gray between mu opioid receptors and the $\mathrm{NR}_{1}$ subunit of NMDA channels (Rodriguez-Munoz et al., 2012). Disruption of the complex by morphine contributed to the development of tolerance (Rodriguez-Munoz et al., 2012). Considering the ubiquitous distribution of the $\mathrm{NR}_{1}$ subunit, mu opioid-NMDA heteromers are likely to form in other brain regions. In addition, mu- $\mathrm{D}_{1}$ and $\mathrm{D}_{1}$-NMDA heteromers have been identified in the striatum suggesting the possibility of larger heterocomplexes that may represent a yet unrecognized modulator of neuronal activity contributing to SUD.

\section{Heteromers as novel therapeutic targets}

Vvery few novel pharmacological targets have proven effective in the clinic over the past three to four decades. Only minimal advances have been made, which emphasizes the need to address SUD treatment from a different perspective. Heteromerization as a mean for different GPCRs to alter behaviour by functioning together may therefore represents an alternative way to think about biological underpinnings of addiction. Indeed, heteromers have been detected in the human brain as for dopamine $\mathrm{D}_{1}-\mathrm{D}_{2}$ and $5 \mathrm{HT}_{2 \mathrm{a}}-\mathrm{mGlu}_{2}$ pairs (GonzalezMaeso et al., 2008; Pei et al., 2010). In preclinical models, unambiguous implication in SUD has now been established for several receptor pairs. Although this identifies heteromers as novel therapeutic targets, the design of selective ligands is still in its infancy.

Bivalent ligands have been developed to simultaneously bind two receptors in physical contact. Administration (i.c.v.) of the bivalent ligand MDAN-21 composed of the mu agonist oxymorphone and the delta antagonist naltrindole induced analgesia with low tolerance and low physical dependence (Daniels et al., 2005). This provided a proof of concept that the 
strategy is of therapeutic interest. Selective targeting of mu-delta heteromers may indeed represent a valuable option, in particular for patients on opiate maintenance treatment.

Integrated dual acting drugs combining heteromer selective targeting with a mixed agonist/ antagonist profile were also explored as a therapeutic approach. The strategy has been validated with eluxadoline, a mixed mu opioid agonist delta opioid antagonist recently approved by the FDA (Viberzi) for the treatment of irritable bowel syndrome. Arguments in favor of binding to mu-delta heteromers include lower efficacy in mice deficient for the delta opioid receptor and reduced signaling in the presence of mu-delta selective antibodies (Fujita et al., 2014). In the context of SUD, targeting $\mathrm{A}_{2 \mathrm{a}}-\mathrm{D}_{2}$ heteromers with a mixed $\mathrm{A}_{2 \mathrm{a}}$-antagonistD2 agonist (Jorg et al., 2015) may have therapeutic application by reducing habit formation developing upon chronic usage of psychostimulants.

Attempts were also made to develop biased ligands with preferential affinity for heteromers. SKF83959 specifically targets D1-D2 heteromers and attenuates cocaine-induced locomotor sensitization and reinforcing properties as well as reinstatement of cocaine seeking (Hasbi et al., 2018). CYM51010, a monovalent ligand with preferential affinity for mu-delta heteromers, induced potent thermal analgesia comparable to morphine but lower tolerance and physical dependence (Gomes et al., 2013). Since CYM51010 showed no rewarding properties, this ligand is currently evaluated in preclinical models as an alternative to current opiate maintenance strategies such as methadone or buprenorphine (Massotte unpublished results).

Finally, the concept of signalosome is also gaining importance in the context of SUD. Based on established physical proximity, complexes involving adenosine $A_{2 a}$, dopamine $D_{2}$, sigma1 receptors and N-type channels, composed of histamine $\mathrm{H}_{3}$, dopamine $\mathrm{D}_{1}$, sigma1 receptors and N-types channel or associating mu opioid, dopamine $\mathrm{D}_{1}$ and NMDA channels can now be reasonably postulated as plausible SUD-relevant functional units that fine-tune intracellular cascades. These large protein aggregates form signaling platforms and represent 
an extended view of the current concept of heteromerization. Better characterization of these large functional ensembles should therefore pave the way to novel therapeutic options.

\section{Acknowledgements}

We would like to thank Dr Cella Olmstead for fruitful discussions and critical reading of the manuscript. 


\section{References}

Altier, C., Khosravani, H., Evans, R.M., Hameed, S., Peloquin, J.B., Vartian, B.A., Chen, L., Beedle, A.M., Ferguson, S.S., Mezghrani, A., Dubel, S.J., Bourinet, E., McRory, J.E., Zamponi, G.W., 2006. ORL1 receptor-mediated internalization of N-type calcium channels. Nat Neurosci 9, 31-40.

Arolfo, M.P., Yao, L., Gordon, A.S., Diamond, I., Janak, P.H., 2004. Ethanol operant selfadministration in rats is regulated by adenosine A2 receptors. Alcohol Clin Exp Res 28, 1308-1316.

Bagot, K.S., Milin, R., Kaminer, Y., 2015. Adolescent Initiation of Cannabis Use and EarlyOnset Psychosis. Subst Abus 36, 524-533.

Bakker, R.A., Lozada, A.F., van Marle, A., Shenton, F.C., Drutel, G., Karlstedt, K., Hoffmann, M., Lintunen, M., Yamamoto, Y., van Rijn, R.M., Chazot, P.L., Panula, P., Leurs, R., 2006. Discovery of naturally occurring splice variants of the rat histamine H3 receptor that act as dominant-negative isoforms. Mol Pharmacol 69, 1194-1206.

Baragli, A., Alturaihi, H., Watt, H.L., Abdallah, A., Kumar, U., 2007. Heterooligomerization of human dopamine receptor 2 and somatostatin receptor 2 Co-immunoprecipitation and fluorescence resonance energy transfer analysis. Cell Signal 19, 2304-2316.

Beedle, A.M., McRory, J.E., Poirot, O., Doering, C.J., Altier, C., Barrere, C., Hamid, J., Nargeot, J., Bourinet, E., Zamponi, G.W., 2004. Agonist-independent modulation of Ntype calcium channels by ORL1 receptors. Nat Neurosci 7, 118-125.

Beer, B., Erb, R., Pavlic, M., Ulmer, H., Giacomuzzi, S., Riemer, Y., Oberacher, H., 2013. Association of polymorphisms in pharmacogenetic candidate genes (OPRD1, GAL, ABCB1, OPRM1) with opioid dependence in European population: a case-control study. PLoS One 8, e75359. 
Beggiato, S., Borelli, A.C., Borroto-Escuela, D., Corbucci, I., Tomasini, M.C., Marti, M., Antonelli, T., Tanganelli, S., Fuxe, K., Ferraro, L., 2017. Cocaine modulates allosteric D2-sigma1 receptor-receptor interactions on dopamine and glutamate nerve terminals from rat striatum. Cell Signal 40, 116-124.

Beggiato, S., Tomasini, M.C., Borelli, A.C., Borroto-Escuela, D.O., Fuxe, K., Antonelli, T., Tanganelli, S., Ferraro, L., 2016. Functional role of striatal A2A, D2, and mGlu5 receptor interactions in regulating striatopallidal GABA neuronal transmission. J Neurochem 138 , 254-264.

Bonaventura, J., Navarro, G., Casado-Anguera, V., Azdad, K., Rea, W., Moreno, E., Brugarolas, M., Mallol, J., Canela, E.I., Lluis, C., Cortes, A., Volkow, N.D., Schiffmann, S.N., Ferre, S., Casado, V., 2015. Allosteric interactions between agonists and antagonists within the adenosine A2A receptor-dopamine D2 receptor heterotetramer. Proc Natl Acad Sci U S A 112, E3609-3618.

Borroto-Escuela, D.O., Narvaez, M., Wydra, K., Pintsuk, J., Pinton, L., Jimenez-Beristain, A., Di Palma, M., Jastrzebska, J., Filip, M., Fuxe, K., 2017. Cocaine self-administration specifically increases A2AR-D2R and D2R-sigma1R heteroreceptor complexes in the rat nucleus accumbens shell. Relevance for cocaine use disorder. Pharmacol Biochem Behav $155,24-31$.

Borroto-Escuela, D.O., Pintsuk, J., Schafer, T., Friedland, K., Ferraro, L., Tanganelli, S., Liu, F., Fuxe, K., 2016. Multiple D2 heteroreceptor complexes: new targets for treatment of schizophrenia. Ther Adv Psychopharmacol 6, 77-94.

Borroto-Escuela, D.O., Romero-Fernandez, W., Tarakanov, A.O., Gomez-Soler, M., Corrales, F., Marcellino, D., Narvaez, M., Frankowska, M., Flajolet, M., Heintz, N., Agnati, L.F., Ciruela, F., Fuxe, K., 2010. Characterization of the A2AR-D2R interface: focus on the 
role of the C-terminal tail and the transmembrane helices. Biochem Biophys Res Commun 402, 801-807.

Borroto-Escuela, D.O., Wydra, K., Li, X., Rodriguez, D., Carlsson, J., Jastrzebska, J., Filip, M., Fuxe, K., 2018. Disruption of A2AR-D2R Heteroreceptor Complexes After A2AR Transmembrane 5 Peptide Administration Enhances Cocaine Self-Administration in Rats. Mol Neurobiol.

Boyer, S.B., Clancy, S.M., Terunuma, M., Revilla-Sanchez, R., Thomas, S.M., Moss, S.J., Slesinger, P.A., 2009. Direct interaction of GABAB receptors with M2 muscarinic receptors enhances muscarinic signaling. J Neurosci 29, 15796-15809.

Bushlin, I., Gupta, A., Stockton, S.D., Jr., Miller, L.K., Devi, L.A., 2012. Dimerization with cannabinoid receptors allosterically modulates delta opioid receptor activity during neuropathic pain. PLoS One 7, e49789.

Callen, L., Moreno, E., Barroso-Chinea, P., Moreno-Delgado, D., Cortes, A., Mallol, J., Casado, V., Lanciego, J.L., Franco, R., Lluis, C., Canela, E.I., McCormick, P.J., 2012. Cannabinoid receptors $\mathrm{CB} 1$ and $\mathrm{CB} 2$ form functional heteromers in brain. J Biol Chem $287,20851-20865$.

Capper-Loup, C., Canales, J.J., Kadaba, N., Graybiel, A.M., 2002. Concurrent activation of dopamine D1 and D2 receptors is required to evoke neural and behavioral phenotypes of cocaine sensitization. J Neurosci 22, 6218-6227.

Carriba, P., Ortiz, O., Patkar, K., Justinova, Z., Stroik, J., Themann, A., Muller, C., Woods, A.S., Hope, B.T., Ciruela, F., Casado, V., Canela, E.I., Lluis, C., Goldberg, S.R., Moratalla, R., Franco, R., Ferre, S., 2007. Striatal adenosine A2A and cannabinoid CB1 receptors form functional heteromeric complexes that mediate the motor effects of cannabinoids. Neuropsychopharmacology 32, 2249-2259. 
Charles, K.J., Evans, M.L., Robbins, M.J., Calver, A.R., Leslie, R.A., Pangalos, M.N., 2001. Comparative immunohistochemical localisation of $\mathrm{GABA}(\mathrm{B} 1 \mathrm{a}), \mathrm{GABA}(\mathrm{B} 1 \mathrm{~b})$ and GABA(B2) subunits in rat brain, spinal cord and dorsal root ganglion. Neuroscience 106, 447-467.

Ciruela, F., Burgueno, J., Casado, V., Canals, M., Marcellino, D., Goldberg, S.R., Bader, M., Fuxe, K., Agnati, L.F., Lluis, C., Franco, R., Ferre, S., Woods, A.S., 2004. Combining mass spectrometry and pull-down techniques for the study of receptor heteromerization. Direct epitope-epitope electrostatic interactions between adenosine A2A and dopamine D2 receptors. Anal Chem 76, 5354-5363.

Ciruela, F., Casado, V., Rodrigues, R.J., Lujan, R., Burgueno, J., Canals, M., Borycz, J., Rebola, N., Goldberg, S.R., Mallol, J., Cortes, A., Canela, E.I., Lopez-Gimenez, J.F., Milligan, G., Lluis, C., Cunha, R.A., Ferre, S., Franco, R., 2006. Presynaptic control of striatal glutamatergic neurotransmission by adenosine A1-A2A receptor heteromers. J Neurosci 26, 2080-2087.

Contet, C., Kieffer, B.L., Befort, K., 2004. Mu opioid receptor: a gateway to drug addiction. Curr Opin Neurobiol 14, 370-378.

Cunha-Oliveira, T., Rego, A.C., Oliveira, C.R., 2008. Cellular and molecular mechanisms involved in the neurotoxicity of opioid and psychostimulant drugs. Brain Res Rev 58, 192-208.

Daniels, D.J., Lenard, N.R., Etienne, C.L., Law, P.Y., Roerig, S.C., Portoghese, P.S., 2005. Opioid-induced tolerance and dependence in mice is modulated by the distance between pharmacophores in a bivalent ligand series. Proc Natl Acad Sci U S A 102, 19208-19213.

Das, S., Barnwal, P., Ramasamy, A., Sen, S., Mondal, S., 2016. Lysergic acid diethylamide: a drug of 'use'? Ther Adv Psychopharmacol 6, 214-228. 
Décaillot, F.M., Rozenfeld, R., Gupta, A., Devi, L.A., 2008. Cell surface targeting of mu-delta opioid receptor heterodimers by RTP4. Proc Natl Acad Sci U S A 105, 16045-16050.

Derouiche, L., Ory, S., Massotte, D., 2018. Double fluorescent knock-in mice to investigate endogenous mu-delta opioid heteromer subscellular distribution., in: Escuela, K.F.a.D.B. (Ed.), Receptor-Receptor Interactions in the Central Nervous System. Springer US.

Dunwiddie, T.V., Masino, S.A., 2001. The role and regulation of adenosine in the central nervous system. Annu Rev Neurosci 24, 31-55.

El Yacoubi, M., Ledent, C., Parmentier, M., Daoust, M., Costentin, J., Vaugeois, J., 2001. Absence of the adenosine $\mathrm{A}(2 \mathrm{~A})$ receptor or its chronic blockade decrease ethanol withdrawal-induced seizures in mice. Neuropharmacology 40, 424-432.

Ellenbroek, B.A., 2013. Histamine H(3) receptors, the complex interaction with dopamine and its implications for addiction. Br J Pharmacol 170, 46-57.

Elmhurst, J.L., Xie, Z., O'Dowd, B.F., George, S.R., 2000. The splice variant D3nf reduces ligand binding to the D3 dopamine receptor: evidence for heterooligomerization. Brain Res Mol Brain Res 80, 63-74.

Erbs, E., Faget, L., Scherrer, G., Matifas, A., Filliol, D., Vonesch, J.L., Koch, M., Kessler, P., Hentsch, D., Birling, M.C., Koutsourakis, M., Vasseur, L., Veinante, P., Kieffer, B.L., Massotte, D., 2015. A mu-delta opioid receptor brain atlas reveals neuronal cooccurrence in subcortical networks. Brain Struct Funct 220, 677-702.

Evans, R.M., You, H., Hameed, S., Altier, C., Mezghrani, A., Bourinet, E., Zamponi, G.W., 2010. Heterodimerization of ORL1 and opioid receptors and its consequences for N-type calcium channel regulation. J Biol Chem 285, 1032-1040.

Feltmann, K., Borroto-Escuela, D.O., Ruegg, J., Pinton, L., de Oliveira Sergio, T., Narvaez, M., Jimenez-Beristain, A., Ekstrom, T.J., Fuxe, K., Steensland, P., 2018. Effects of Long- 
Term Alcohol Drinking on the Dopamine D2 Receptor: Gene Expression and Heteroreceptor Complexes in the Striatum in Rats. Alcohol Clin Exp Res 42, 338-351. Fernandez-Duenas, V., Llorente, J., Gandia, J., Borroto-Escuela, D.O., Agnati, L.F., Tasca, C.I., Fuxe, K., Ciruela, F., 2012. Fluorescence resonance energy transfer-based technologies in the study of protein-protein interactions at the cell surface. Methods 57, $467-472$.

Fernandez-Duenas, V., Taura, J.J., Cottet, M., Gomez-Soler, M., Lopez-Cano, M., Ledent, C., Watanabe, M., Trinquet, E., Pin, J.P., Lujan, R., Durroux, T., Ciruela, F., 2015. Untangling dopamine-adenosine receptor-receptor assembly in experimental parkinsonism in rats. Dis Model Mech 8, 57-63.

Ferrada, C., Moreno, E., Casado, V., Bongers, G., Cortes, A., Mallol, J., Canela, E.I., Leurs, R., Ferre, S., Lluis, C., Franco, R., 2009. Marked changes in signal transduction upon heteromerization of dopamine D1 and histamine H3 receptors. Br J Pharmacol 157, 6475.

Ferraguti, F., Shigemoto, R., 2006. Metabotropic glutamate receptors. Cell Tissue Res 326, 483-504.

Ferre, S., 2016. Mechanisms of the psychostimulant effects of caffeine: implications for substance use disorders. Psychopharmacology (Berl) 233, 1963-1979.

Ferre, S., Bonaventura, J., Zhu, W., Hatcher, C., Taura, J., Quiroz, C., Cai, N.S., Moreno, E., Casado-Anguera, V., Kravitz, A.V., Thompson, K.R., Tomasi, D., Navarro, G., Cordomi, A., Pardo, L., Lluis, C., Dessauer, C.W., Volkow, N.D., Casado, V., Ciruela, F., Logothetis, D.E., Zwilling, D., 2018. Essential Control of the Function of the Striatopallidal Neuron by Pre-coupled Complexes of Adenosine A2A-Dopamine D2 Receptor Heterotetramers and Adenylyl Cyclase. Front Pharmacol 9, 243. 
Ferre, S., Casado, V., Devi, L.A., Filizola, M., Jockers, R., Lohse, M.J., Milligan, G., Pin, J.P., Guitart, X., 2014. G protein-coupled receptor oligomerization revisited: functional and pharmacological perspectives. Pharmacol Rev 66, 413-434.

Ferre, S., Karcz-Kubicha, M., Hope, B.T., Popoli, P., Burgueno, J., Gutierrez, M.A., Casado, V., Fuxe, K., Goldberg, S.R., Lluis, C., Franco, R., Ciruela, F., 2002. Synergistic interaction between adenosine A2A and glutamate mGlu5 receptors: implications for striatal neuronal function. Proc Natl Acad Sci U S A 99, 11940-11945.

Ferreira, S.G., Goncalves, F.Q., Marques, J.M., Tome, A.R., Rodrigues, R.J., Nunes-Correia, I., Ledent, C., Harkany, T., Venance, L., Cunha, R.A., Kofalvi, A., 2015. Presynaptic adenosine A2A receptors dampen cannabinoid CB1 receptor-mediated inhibition of corticostriatal glutamatergic transmission. Br J Pharmacol 172, 1074-1086.

Fiorentini, C., Busi, C., Gorruso, E., Gotti, C., Spano, P., Missale, C., 2008. Reciprocal regulation of dopamine D1 and D3 receptor function and trafficking by heterodimerization. Mol Pharmacol 74, 59-69.

Fiorentini, C., Gardoni, F., Spano, P., Di Luca, M., Missale, C., 2003. Regulation of dopamine D1 receptor trafficking and desensitization by oligomerization with glutamate N-methylD-aspartate receptors. J Biol Chem 278, 20196-20202.

Fredriksson, R., Schioth, H.B., 2005. The repertoire of G-protein-coupled receptors in fully sequenced genomes. Mol Pharmacol 67, 1414-1425.

Friberg, I.K., Young, A.B., Standaert, D.G., 1998. Differential localization of the mRNAs for the pertussis toxin insensitive G-protein alpha sub-units Gq, G11, and Gz in the rat brain, and regulation of their expression after striatal deafferentation. Brain Res Mol Brain Res 54, 298-310.

Fribourg, M., Moreno, J.L., Holloway, T., Provasi, D., Baki, L., Mahajan, R., Park, G., Adney, S.K., Hatcher, C., Eltit, J.M., Ruta, J.D., Albizu, L., Li, Z., Umali, A., Shim, J., Fabiato, 
A., MacKerell, A.D., Jr., Brezina, V., Sealfon, S.C., Filizola, M., Gonzalez-Maeso, J., Logothetis, D.E., 2011. Decoding the signaling of a GPCR heteromeric complex reveals a unifying mechanism of action of antipsychotic drugs. Cell 147, 1011-1023.

Fujita, W., Gomes, I., Dove, L.S., Prohaska, D., McIntyre, G., Devi, L.A., 2014. Molecular characterization of eluxadoline as a potential ligand targeting mu-delta opioid receptor heteromers. Biochem Pharmacol 92, 448-456.

Furlong, T.M., Supit, A.S., Corbit, L.H., Killcross, S., Balleine, B.W., 2017. Pulling habits out of rats: adenosine $2 \mathrm{~A}$ receptor antagonism in dorsomedial striatum rescues methamphetamine-induced deficits in goal-directed action. Addict Biol 22, 172-183.

Fuxe, K., Marcellino, D., Leo, G., Agnati, L.F., 2010. Molecular integration via allosteric interactions in receptor heteromers. A working hypothesis. Curr Opin Pharmacol 10, 1422.

Gaitonde, S.A., Gonzalez-Maeso, J., 2017. Contribution of heteromerization to G proteincoupled receptor function. Curr Opin Pharmacol 32, 23-31.

Garcia-Cabrerizo, R., Garcia-Fuster, M.J., 2016. Opposite regulation of cannabinoid CB1 and CB2 receptors in the prefrontal cortex of rats treated with cocaine during adolescence. Neurosci Lett 615, 60-65.

Gendron, L., Mittal, N., Beaudry, H., Walwyn, W., 2015. Recent advances on the delta opioid receptor: from trafficking to function. Br J Pharmacol 172, 403-419.

George, S.R., Fan, T., Xie, Z., Tse, R., Tam, V., Varghese, G., O'Dowd, B.F., 2000. Oligomerization of mu- and delta-opioid receptors. Generation of novel functional properties. Journal of Biological Chemistry 275, 26128-26135.

Golebiewska, U., Johnston, J.M., Devi, L., Filizola, M., Scarlata, S., 2011. Differential response to morphine of the oligomeric state of mu-opioid in the presence of delta-opioid receptors. Biochemistry 50, 2829-2837. 
Gomes, I., Fujita, W., Gupta, A., Saldanha, S.A., Negri, A., Pinello, C.E., Eberhart, C., Roberts, E., Filizola, M., Hodder, P., Devi, L.A., 2013. Identification of a mu-delta opioid receptor heteromer-biased agonist with antinociceptive activity. Proc Natl Acad Sci U S A 110, 12072-12077.

Gomes, I., Gupta, A., Filipovska, J., Szeto, H.H., Pintar, J.E., Devi, L.A., 2004. A role for heterodimerization of mu and delta opiate receptors in enhancing morphine analgesia. Proc Natl Acad Sci U S A 101, 5135-5139.

Gomes, I., Ijzerman, A.P., Ye, K., Maillet, E.L., Devi, L.A., 2011. G protein-coupled receptor heteromerization: a role in allosteric modulation of ligand binding. Mol Pharmacol 79, 1044-1052.

Gomes, I., Jordan, B.A., Gupta, A., Trapaidze, N., Nagy, V., Devi, L.A., 2000. Heterodimerization of mu and delta opioid receptors: a role in opiate synergy. Journal of Neuroscience 20, 1-5.

Gonzalez-Maeso, J., Ang, R.L., Yuen, T., Chan, P., Weisstaub, N.V., Lopez-Gimenez, J.F., Zhou, M., Okawa, Y., Callado, L.F., Milligan, G., Gingrich, J.A., Filizola, M., Meana, J.J., Sealfon, S.C., 2008. Identification of a serotonin/glutamate receptor complex implicated in psychosis. Nature 452, 93-97.

Gupta, A., Mulder, J., Gomes, I., Rozenfeld, R., Bushlin, I., Ong, E., Lim, M., Maillet, E., Junek, M., Cahill, C.M., Harkany, T., Devi, L.A., 2010. Increased abundance of opioid receptor heteromers after chronic morphine administration. Sci Signal 3, ra54.

Han, Y., Moreira, I.S., Urizar, E., Weinstein, H., Javitch, J.A., 2009. Allosteric communication between protomers of dopamine class A GPCR dimers modulates activation. Nat Chem Biol 5, 688-695. 
Hasbi, A., Fan, T., Alijaniaram, M., Nguyen, T., Perreault, M.L., O'Dowd, B.F., George, S.R., 2009. Calcium signaling cascade links dopamine D1-D2 receptor heteromer to striatal BDNF production and neuronal growth. Proc Natl Acad Sci U S A 106, 21377-21382.

Hasbi, A., O'Dowd, B.F., George, S.R., 2011. Dopamine D1-D2 receptor heteromer signaling pathway in the brain: emerging physiological relevance. Mol Brain 4, 26.

Hasbi, A., Perreault, M.L., Shen, M.Y.F., Fan, T., Nguyen, T., Alijaniaram, M., Banasikowski, T.J., Grace, A.A., O'Dowd, B.F., Fletcher, P.J., George, S.R., 2018. Activation of Dopamine D1-D2 Receptor Complex Attenuates Cocaine Reward and Reinstatement of Cocaine-Seeking through Inhibition of DARPP-32, ERK, and DeltaFosB. Front Pharmacol 8, 924.

Hawes, J.J., Brunzell, D.H., Narasimhaiah, R., Langel, U., Wynick, D., Picciotto, M.R., 2008. Galanin protects against behavioral and neurochemical correlates of opiate reward. Neuropsychopharmacology 33, 1864-1873.

Hawes, J.J., Picciotto, M.R., 2004. Characterization of GalR1, GalR2, and GalR3 immunoreactivity in catecholaminergic nuclei of the mouse brain. J Comp Neurol 479, $410-423$.

He, S.Q., Zhang, Z.N., Guan, J.S., Liu, H.R., Zhao, B., Wang, H.B., Li, Q., Yang, H., Luo, J., Li, Z.Y., Wang, Q., Lu, Y.J., Bao, L., Zhang, X., 2011. Facilitation of mu-opioid receptor activity by preventing delta-opioid receptor-mediated codegradation. Neuron $69,120-$ 131.

He, Y., Li, Y., Chen, M., Pu, Z., Zhang, F., Chen, L., Ruan, Y., Pan, X., He, C., Chen, X., Li, Z., Chen, J.F., 2016. Habit Formation after Random Interval Training Is Associated with Increased Adenosine A2A Receptor and Dopamine D2 Receptor Heterodimers in the Striatum. Front Mol Neurosci 9, 151. 
Hendry, I.A., Kelleher, K.L., Bartlett, S.E., Leck, K.J., Reynolds, A.J., Heydon, K., Mellick, A., Megirian, D., Matthaei, K.I., 2000. Hypertolerance to morphine in G(z alpha)deficient mice. Brain Res 870, 10-19.

Hillion, J., Canals, M., Torvinen, M., Casado, V., Scott, R., Terasmaa, A., Hansson, A., Watson, S., Olah, M.E., Mallol, J., Canela, E.I., Zoli, M., Agnati, L.F., Ibanez, C.F., Lluis, C., Franco, R., Ferre, S., Fuxe, K., 2002. Coaggregation, cointernalization, and codesensitization of adenosine A2A receptors and dopamine D2 receptors. J Biol Chem 277, 18091-18097.

Huang, C.C., Lo, S.W., Hsu, K.S., 2001. Presynaptic mechanisms underlying cannabinoid inhibition of excitatory synaptic transmission in rat striatal neurons. J Physiol 532, 731748.

Huang, L., Wu, D.D., Zhang, L., Feng, L.Y., 2013. Modulation of A(2)a receptor antagonist on $\mathrm{D}(2)$ receptor internalization and ERK phosphorylation. Acta Pharmacol Sin 34, $1292-1300$.

Jones, K.A., Borowsky, B., Tamm, J.A., Craig, D.A., Durkin, M.M., Dai, M., Yao, W.J., Johnson, M., Gunwaldsen, C., Huang, L.Y., Tang, C., Shen, Q., Salon, J.A., Morse, K., Laz, T., Smith, K.E., Nagarathnam, D., Noble, S.A., Branchek, T.A., Gerald, C., 1998. $\mathrm{GABA}(\mathrm{B})$ receptors function as a heteromeric assembly of the subunits $\mathrm{GABA}(\mathrm{B}) \mathrm{R} 1$ and GABA(B)R2. Nature 396, 674-679.

Jordan, B.A., Gomes, I., Rios, C., Filipovska, J., Devi, L.A., 2003. Functional interactions between mu opioid and alpha 2A-adrenergic receptors. Mol Pharmacol 64, 1317-1324.

Jorg, M., May, L.T., Mak, F.S., Lee, K.C., Miller, N.D., Scammells, P.J., Capuano, B., 2015. Synthesis and pharmacological evaluation of dual acting ligands targeting the adenosine A2A and dopamine D2 receptors for the potential treatment of Parkinson's disease. J Med Chem 58, 718-738. 
Joseph, L., Thomsen, M., 2017. Effects of muscarinic receptor antagonists on cocaine discrimination in wild-type mice and in muscarinic receptor M1, M2, and M4 receptor knockout mice. Behav Brain Res 329, 75-83.

Kabli, N., Fan, T., O'Dowd, B.F., George, S.R., 2014. mu-delta opioid receptor heteromerspecific signaling in the striatum and hippocampus. Biochem Biophys Res Commun 450, 906-911.

Kabli, N., Martin, N., Fan, T., Nguyen, T., Hasbi, A., Balboni, G., O'Dowd, B.F., George, S.R., 2010. Agonists at the delta-opioid receptor modify the binding of micro-receptor agonists to the micro-delta receptor hetero-oligomer. Br J Pharmacol 161, 1122-1136.

Kabli, N., Nguyen, T., Balboni, G., O'Dowd, B.F., George, S.R., 2013. Antidepressant-like and anxiolytic-like effects following activation of the mu-delta opioid receptor heteromer in the nucleus accumbens. Mol Psychiatry.

Kamp, M.A., Hanggi, D., Steiger, H.J., Schneider, T., 2012. Diversity of presynaptic calcium channels displaying different synaptic properties. Rev Neurosci 23, 179-190.

Karila, L., Roux, P., Rolland, B., Benyamina, A., Reynaud, M., Aubin, H.J., Lancon, C., 2014. Acute and long-term effects of cannabis use: a review. Curr Pharm Des 20, 4112-4118.

Karoly, H.C., YorkWilliams, S.L., Hutchison, K.E., 2015. Clinical neuroscience of addiction: similarities and differences between alcohol and other drugs. Alcohol Clin Exp Res 39, 2073-2084.

Karpa, K.D., Lin, R., Kabbani, N., Levenson, R., 2000. The dopamine D3 receptor interacts with itself and the truncated D3 splice variant d3nf: D3-D3nf interaction causes mislocalization of D3 receptors. Mol Pharmacol 58, 677-683.

Khelashvili, G., Dorff, K., Shan, J., Camacho-Artacho, M., Skrabanek, L., Vroling, B., Bouvier, M., Devi, L.A., George, S.R., Javitch, J.A., Lohse, M.J., Milligan, G., Neubig, R.R., Palczewski, K., Parmentier, M., Pin, J.P., Vriend, G., Campagne, F., Filizola, M., 
2010. GPCR-OKB: the G Protein Coupled Receptor Oligomer Knowledge Base. Bioinformatics 26, 1804-1805.

Kisilevsky, A.E., Mulligan, S.J., Altier, C., Iftinca, M.C., Varela, D., Tai, C., Chen, L., Hameed, S., Hamid, J., Macvicar, B.A., Zamponi, G.W., 2008. D1 receptors physically interact with $\mathrm{N}$-type calcium channels to regulate channel distribution and dendritic calcium entry. Neuron 58, 557-570.

Kisilevsky, A.E., Zamponi, G.W., 2008. D2 dopamine receptors interact directly with N-type calcium channels and regulate channel surface expression levels. Channels (Austin) 2, 269-277.

Kononoff Vanhanen, J., Nuutinen, S., Tuominen, M., Panula, P., 2016. Histamine H3 Receptor Regulates Sensorimotor Gating and Dopaminergic Signaling in the Striatum. J Pharmacol Exp Ther 357, 264-272.

Koob, G.F., Volkow, N.D., 2010. Neurocircuitry of addiction. Neuropsychopharmacology 35, 217-238.

Kramp, B.K., Sarabi, A., Koenen, R.R., Weber, C., 2011. Heterophilic chemokine receptor interactions in chemokine signaling and biology. Exp Cell Res 317, 655-663.

Kuo, S.C., Yeh, Y.W., Chen, C.Y., Huang, C.C., Chang, H.A., Yen, C.H., Ho, P.S., Liang, C.S., Chou, H.W., Lu, R.B., Huang, S.Y., 2014. DRD3 variation associates with earlyonset heroin dependence, but not specific personality traits. Prog Neuropsychopharmacol Biol Psychiatry 51, 1-8.

Lee, S.P., So, C.H., Rashid, A.J., Varghese, G., Cheng, R., Lanca, A.J., O'Dowd, B.F., George, S.R., 2004. Dopamine D1 and D2 receptor Co-activation generates a novel phospholipase C-mediated calcium signal. J Biol Chem 279, 35671-35678.

Maggio, R., Rocchi, C., Scarselli, M., 2013. Experimental strategies for studying G proteincoupled receptor homo- and heteromerization with radioligand binding and signal 
transduction methods, in: Conn, P.M. (Ed.), Methods in Enzymology: G protein coupled receptors trafficking and oligomerization. Elsevier Inc, pp. 295-310.

Manduca, A., Lassalle, O., Sepers, M., Campolongo, P., Cuomo, V., Marsicano, G., Kieffer, B., Vanderschuren, L.J., Trezza, V., Manzoni, O.J., 2016. Interacting Cannabinoid and Opioid Receptors in the Nucleus Accumbens Core Control Adolescent Social Play. Front Behav Neurosci 10, 211.

Marcellino, D., Ferre, S., Casado, V., Cortes, A., Le Foll, B., Mazzola, C., Drago, F., Saur, O., Stark, H., Soriano, A., Barnes, C., Goldberg, S.R., Lluis, C., Fuxe, K., Franco, R., 2008. Identification of dopamine D1-D3 receptor heteromers. Indications for a role of synergistic D1-D3 receptor interactions in the striatum. J Biol Chem 283, 26016-26025.

Marcellino, D., Navarro, G., Sahlholm, K., Nilsson, J., Agnati, L.F., Canela, E.I., Lluis, C., Arhem, P., Franco, R., Fuxe, K., 2010. Cocaine produces D2R-mediated conformational changes in the adenosine $\mathrm{A}(2 \mathrm{~A}) \mathrm{R}$-dopamine $\mathrm{D} 2 \mathrm{R}$ heteromer. Biochem Biophys Res Commun 394, 988-992.

Marcellino, D., Roberts, D.C., Navarro, G., Filip, M., Agnati, L., Lluis, C., Franco, R., Fuxe, K., 2007. Increase in A2A receptors in the nucleus accumbens after extended cocaine self-administration and its disappearance after cocaine withdrawal. Brain Res 1143, 208220.

Margolis, E.B., Fujita, W., Devi, L.A., Fields, H.L., 2017. Two delta opioid receptor subtypes are functional in single ventral tegmental area neurons, and can interact with the mu opioid receptor. Neuropharmacology 123, 420-432.

Martin, A.B., Fernandez-Espejo, E., Ferrer, B., Gorriti, M.A., Bilbao, A., Navarro, M., Rodriguez de Fonseca, F., Moratalla, R., 2008. Expression and function of CB1 receptor in the rat striatum: localization and effects on D1 and D2 dopamine receptor-mediated motor behaviors. Neuropsychopharmacology 33, 1667-1679. 
Matsumoto, R.R., McCracken, K.A., Pouw, B., Zhang, Y., Bowen, W.D., 2002. Involvement of sigma receptors in the behavioral effects of cocaine: evidence from novel ligands and antisense oligodeoxynucleotides. Neuropharmacology 42, 1043-1055.

Matyas, F., Yanovsky, Y., Mackie, K., Kelsch, W., Misgeld, U., Freund, T.F., 2006. Subcellular localization of type 1 cannabinoid receptors in the rat basal ganglia. Neuroscience 137, 337-361.

Mei, J., Pasternak, G.W., 2001. Molecular cloning and pharmacological characterization of the rat sigma1 receptor. Biochem Pharmacol 62, 349-355.

Melik Parsadaniantz, S., Rivat, C., Rostene, W., Reaux-Le Goazigo, A., 2015. Opioid and chemokine receptor crosstalk: a promising target for pain therapy? Nat Rev Neurosci 16, $69-78$.

Moreno, E., Hoffmann, H., Gonzalez-Sepulveda, M., Navarro, G., Casado, V., Cortes, A., Mallol, J., Vignes, M., McCormick, P.J., Canela, E.I., Lluis, C., Moratalla, R., Ferre, S., Ortiz, J., Franco, R., 2011a. Dopamine D1-histamine H3 receptor heteromers provide a selective link to MAPK signaling in GABAergic neurons of the direct striatal pathway. J Biol Chem 286, 5846-5854.

Moreno, E., Moreno-Delgado, D., Navarro, G., Hoffmann, H.M., Fuentes, S., Rosell-Vilar, S., Gasperini, P., Rodriguez-Ruiz, M., Medrano, M., Mallol, J., Cortes, A., Casado, V., Lluis, C., Ferre, S., Ortiz, J., Canela, E., McCormick, P.J., 2014. Cocaine disrupts histamine H3 receptor modulation of dopamine D1 receptor signaling: sigma1-D1-H3 receptor complexes as key targets for reducing cocaine's effects. J Neurosci 34, 35453558 .

Moreno, E., Quiroz, C., Rea, W., Cai, N.S., Mallol, J., Cortes, A., Lluis, C., Canela, E.I., Casado, V., Ferre, S., 2017. Functional mu-Opioid-Galanin Receptor Heteromers in the Ventral Tegmental Area. J Neurosci 37, 1176-1186. 
Moreno, J.L., Holloway, T., Albizu, L., Sealfon, S.C., Gonzalez-Maeso, J., 2011b. Metabotropic glutamate mGlu2 receptor is necessary for the pharmacological and behavioral effects induced by hallucinogenic 5-HT2A receptor agonists. Neurosci Lett 493, 76-79.

Moreno, J.L., Muguruza, C., Umali, A., Mortillo, S., Holloway, T., Pilar-Cuellar, F., Mocci, G., Seto, J., Callado, L.F., Neve, R.L., Milligan, G., Sealfon, S.C., Lopez-Gimenez, J.F., Meana, J.J., Benson, D.L., Gonzalez-Maeso, J., 2012. Identification of three residues essential for 5-hydroxytryptamine 2A-metabotropic glutamate 2 (5-HT2A.mGlu2) receptor heteromerization and its psychoactive behavioral function. J Biol Chem 287 , $44301-44319$.

Nader, J., Rapino, C., Gennequin, B., Chavant, F., Francheteau, M., Makriyannis, A., Duranti, A., Maccarrone, M., Solinas, M., Thiriet, N., 2014. Prior stimulation of the endocannabinoid system prevents methamphetamine-induced dopaminergic neurotoxicity in the striatum through activation of CB2 receptors. Neuropharmacology $87,214-221$.

Nam, H.W., Hinton, D.J., Kang, N.Y., Kim, T., Lee, M.R., Oliveros, A., Adams, C., Ruby, C.L., Choi, D.S., 2013. Adenosine transporter ENT1 regulates the acquisition of goaldirected behavior and ethanol drinking through $\mathrm{A} 2 \mathrm{~A}$ receptor in the dorsomedial striatum. J Neurosci 33, 4329-4338.

Navarro, G., Aguinaga, D., Moreno, E., Hradsky, J., Reddy, P.P., Cortes, A., Mallol, J., Casado, V., Mikhaylova, M., Kreutz, M.R., Lluis, C., Canela, E.I., McCormick, P.J., Ferre, S., 2014. Intracellular calcium levels determine differential modulation of allosteric interactions within $\mathrm{G}$ protein-coupled receptor heteromers. Chem Biol 21, 1546-1556. 
Navarro, G., Borroto-Escuela, D., Angelats, E., Etayo, I., Reyes-Resina, I., Pulido-Salgado, M., Rodriguez-Perez, A.I., Canela, E.I., Saura, J., Lanciego, J.L., Labandeira-Garcia, J.L., Saura, C.A., Fuxe, K., Franco, R., 2018a. Receptor-heteromer mediated regulation of endocannabinoid signaling in activated microglia. Role of $\mathrm{CB} 1$ and $\mathrm{CB} 2$ receptors and relevance for Alzheimer's disease and levodopa-induced dyskinesia. Brain Behav Immun $67,139-151$.

Navarro, G., Cordomi, A., Casado-Anguera, V., Moreno, E., Cai, N.S., Cortes, A., Canela, E.I., Dessauer, C.W., Casado, V., Pardo, L., Lluis, C., Ferre, S., 2018b. Evidence for functional pre-coupled complexes of receptor heteromers and adenylyl cyclase. Nat Commun 9, 1242.

Navarro, G., Moreno, E., Bonaventura, J., Brugarolas, M., Farre, D., Aguinaga, D., Mallol, J., Cortes, A., Casado, V., Lluis, C., Ferre, S., Franco, R., Canela, E., McCormick, P.J., 2013. Cocaine inhibits dopamine D2 receptor signaling via sigma-1-D2 receptor heteromers. PLoS One 8, e61245.

Nelson, A.J., Killcross, S., 2013. Accelerated habit formation following amphetamine exposure is reversed by D1, but enhanced by D2, receptor antagonists. Front Neurosci 7, 76.

Nguyen, E.C., McCracken, K.A., Liu, Y., Pouw, B., Matsumoto, R.R., 2005. Involvement of sigma (sigma) receptors in the acute actions of methamphetamine: receptor binding and behavioral studies. Neuropharmacology 49, 638-645.

Nguyen, P.T., Selley, D.E., Sim-Selley, L.J., 2010. Statistical Parametric Mapping reveals ligand and region-specific activation of G-proteins by $\mathrm{CB} 1$ receptors and non-CB1 sites in the 3D reconstructed mouse brain. Neuroimage 52, 1243-1251. 
Nimchinsky, E.A., Hof, P.R., Janssen, W.G., Morrison, J.H., Schmauss, C., 1997. Expression of dopamine D3 receptor dimers and tetramers in brain and in transfected cells. J Biol Chem 272, 29229-29237.

Noori, H.R., Cosa Linan, A., Spanagel, R., 2016. Largely overlapping neuronal substrates of reactivity to drug, gambling, food and sexual cues: A comprehensive meta-analysis. Eur Neuropsychopharmacol 26, 1419-1430.

O'Dowd, B.F., Ji, X., Nguyen, T., George, S.R., 2012. Two amino acids in each of D1 and D2 dopamine receptor cytoplasmic regions are involved in D1-D2 heteromer formation. Biochem Biophys Res Commun 417, 23-28.

O'Neill, C.E., LeTendre, M.L., Bachtell, R.K., 2012. Adenosine A2A receptors in the nucleus accumbens bi-directionally alter cocaine seeking in rats. Neuropsychopharmacology 37 , $1245-1256$.

Ozawa, A., Brunori, G., Mercatelli, D., Wu, J., Cippitelli, A., Zou, B., Xie, X.S., Williams, M., Zaveri, N.T., Low, S., Scherrer, G., Kieffer, B.L., Toll, L., 2015. Knock-In Mice with NOP-eGFP Receptors Identify Receptor Cellular and Regional Localization. J Neurosci $35,11682-11693$.

Panula, P., Nuutinen, S., 2011. Histamine and H3 receptor in alcohol-related behaviors. J Pharmacol Exp Ther 336, 9-16.

Pazos, A., Cortes, R., Palacios, J.M., 1985. Quantitative autoradiographic mapping of serotonin receptors in the rat brain. II. Serotonin-2 receptors. Brain Res 346, 231-249.

Pei, L., Lee, F.J., Moszczynska, A., Vukusic, B., Liu, F., 2004. Regulation of dopamine D1 receptor function by physical interaction with the NMDA receptors. J Neurosci 24, 1149 1158. 
Pei, L., Li, S., Wang, M., Diwan, M., Anisman, H., Fletcher, P.J., Nobrega, J.N., Liu, F., 2010. Uncoupling the dopamine D1-D2 receptor complex exerts antidepressant-like effects. Nat Med 16, 1393-1395.

Pellissier, L.P., Barthet, G., Gaven, F., Cassier, E., Trinquet, E., Pin, J.P., Marin, P., Dumuis, A., Bockaert, J., Baneres, J.L., Claeysen, S., 2011. G protein activation by serotonin type 4 receptor dimers: evidence that turning on two protomers is more efficient. J Biol Chem 286, 9985-9997.

Perreault, M.L., Fan, T., Alijaniaram, M., O'Dowd, B.F., George, S.R., 2012a. Dopamine D1D2 receptor heteromer in dual phenotype GABA/glutamate-coexpressing striatal medium spiny neurons: regulation of BDNF, GAD67 and VGLUT1/2. PLoS One 7, e33348.

Perreault, M.L., Hasbi, A., Alijaniaram, M., Fan, T., Varghese, G., Fletcher, P.J., Seeman, P., O'Dowd, B.F., George, S.R., 2010. The dopamine D1-D2 receptor heteromer localizes in dynorphin/enkephalin neurons: increased high affinity state following amphetamine and in schizophrenia. J Biol Chem 285, 36625-36634.

Perreault, M.L., Hasbi, A., Alijaniaram, M., O'Dowd, B.F., George, S.R., 2012b. Reduced striatal dopamine D1-D2 receptor heteromer expression and behavioural subsensitivity in juvenile rats. Neuroscience 225, 130-139.

Perreault, M.L., Hasbi, A., Shen, M.Y.F., Fan, T., Navarro, G., Fletcher, P.J., Franco, R., Lanciego, J.L., George, S.R., 2016. Disruption of a dopamine receptor complex amplifies the actions of cocaine. Eur Neuropsychopharmacol 26, 1366-1377.

Pierce, R.C., Quick, E.A., Reeder, D.C., Morgan, Z.R., Kalivas, P.W., 1998. Calcium-mediated second messengers modulate the expression of behavioral sensitization to cocaine. $\mathrm{J}$ Pharmacol Exp Ther 286, 1171-1176. 
Pin, J.P., Neubig, R., Bouvier, M., Devi, L., Filizola, M., Javitch, J.A., Lohse, M.J., Milligan, G., Palczewski, K., Parmentier, M., Spedding, M., 2007. International Union of Basic and Clinical Pharmacology. LXVII. Recommendations for the recognition and nomenclature of $\mathrm{G}$ protein-coupled receptor heteromultimers. Pharmacol Rev 59, 5-13.

Prieto, G.A., 2017. Abnormalities of Dopamine D3 Receptor Signaling in the Diseased Brain. J Cent Nerv Syst Dis 9, 1179573517726335.

Pritchard, L.M., Logue, A.D., Taylor, B.C., Ahlbrand, R., Welge, J.A., Tang, Y., Sharp, F.R., Richtand, N.M., 2006. Relative expression of D3 dopamine receptor and alternative splice variant D3nf mRNA in high and low responders to novelty. Brain Res Bull 70, 296-303.

Rashid, A.J., So, C.H., Kong, M.M., Furtak, T., El-Ghundi, M., Cheng, R., O'Dowd, B.F., George, S.R., 2007. D1-D2 dopamine receptor heterooligomers with unique pharmacology are coupled to rapid activation of Gq/11 in the striatum. Proc Natl Acad Sci U S A 104, 654-659.

Richtand, N.M., 2006. Behavioral sensitization, alternative splicing, and d3 dopamine receptor-mediated inhibitory function. Neuropsychopharmacology 31, 2368-2375.

Rico, A.J., Dopeso-Reyes, I.G., Martinez-Pinilla, E., Sucunza, D., Pignataro, D., Roda, E., Marin-Ramos, D., Labandeira-Garcia, J.L., George, S.R., Franco, R., Lanciego, J.L., 2017. Neurochemical evidence supporting dopamine D1-D2 receptor heteromers in the striatum of the long-tailed macaque: changes following dopaminergic manipulation. Brain Struct Funct 222, 1767-1784.

Rios, C., Gomes, I., Devi, L.A., 2006. mu opioid and CB1 cannabinoid receptor interactions: reciprocal inhibition of receptor signaling and neuritogenesis. Br J Pharmacol 148, 387395. 
Rodriguez, J.J., Mackie, K., Pickel, V.M., 2001. Ultrastructural localization of the CB1 cannabinoid receptor in mu-opioid receptor patches of the rat Caudate putamen nucleus. J Neurosci 21, 823-833.

Rodriguez-Munoz, M., Sanchez-Blazquez, P., Vicente-Sanchez, A., Berrocoso, E., Garzon, J., 2012. The mu-opioid receptor and the NMDA receptor associate in PAG neurons: implications in pain control. Neuropsychopharmacology 37, 338-349.

Rondard, P., Goudet, C., Kniazeff, J., Pin, J.P., Prezeau, L., 2011. The complexity of their activation mechanism opens new possibilities for the modulation of mGlu and GABAB class C G protein-coupled receptors. Neuropharmacology 60, 82-92.

Rozenfeld, R., Devi, L.A., 2007. Receptor heterodimerization leads to a switch in signaling: beta-arrestin2-mediated ERK activation by mu-delta opioid receptor heterodimers. Faseb J 21, 2455-2465.

Salim, K., Fenton, T., Bacha, J., Urien-Rodriguez, H., Bonnert, T., Skynner, H.A., Watts, E., Kerby, J., Heald, A., Beer, M., McAllister, G., Guest, P.C., 2002. Oligomerization of Gprotein-coupled receptors shown by selective co-immunoprecipitation. J Biol Chem 277, $15482-15485$.

Sambo, D.O., Lebowitz, J.J., Khoshbouei, H., 2018. The sigma-1 receptor as a regulator of dopamine neurotransmission: A potential therapeutic target for methamphetamine addiction. Pharmacol Ther.

Sanchez-Blazquez, P., Gomez-Serranillos, P., Garzon, J., 2001. Agonists determine the pattern of G-protein activation in m-opioid receptor-mediated supraspinal analgesia. Brain Research Bulletin 54, 229-235.

Schmidt, H.R., Zheng, S., Gurpinar, E., Koehl, A., Manglik, A., Kruse, A.C., 2016. Crystal structure of the human sigmal receptor. Nature 532, 527-530. 
Smith, L.N., Bachus, S.E., McDonald, C.G., Smith, R.F., 2015. Role of the D3 dopamine receptor in nicotine sensitization. Behav Brain Res 289, 92-104.

Sokoloff, P., Le Foll, B., 2017. The dopamine D3 receptor, a quarter century later. Eur J Neurosci 45, 2-19.

Soria, G., Castane, A., Berrendero, F., Ledent, C., Parmentier, M., Maldonado, R., Valverde, O., 2004. Adenosine A2A receptors are involved in physical dependence and place conditioning induced by THC. Eur J Neurosci 20, 2203-2213.

Soriano, A., Ventura, R., Molero, A., Hoen, R., Casado, V., Cortes, A., Fanelli, F., Albericio, F., Lluis, C., Franco, R., Royo, M., 2009. Adenosine A2A receptor-antagonist/dopamine D2 receptor-agonist bivalent ligands as pharmacological tools to detect A2A-D2 receptor heteromers. J Med Chem 52, 5590-5602.

Spear, L.P., 2016. Consequences of adolescent use of alcohol and other drugs: Studies using rodent models. Neurosci Biobehav Rev 70, 228-243.

Sun, G.C., Ho, W.Y., Chen, B.R., Cheng, P.W., Cheng, W.H., Hsu, M.C., Yeh, T.C., Hsiao, M., Lu, P.J., Tseng, C.J., 2015. GPCR dimerization in brainstem nuclei contributes to the development of hypertension. Br J Pharmacol 172, 2507-2518.

Tao, Y.M., Yu, C., Wang, W.S., Hou, Y.Y., Xu, X.J., Chi, Z.Q., Ding, Y.Q., Wang, Y.J., Liu, J.G., 2017. Heteromers of mu opioid and dopamine D1 receptors modulate opioidinduced locomotor sensitization in a dopamine-independent manner. Br J Pharmacol 174, $2842-2861$.

Taura, J., Valle-Leon, M., Sahlholm, K., Watanabe, M., Van Craenenbroeck, K., FernandezDuenas, V., Ferre, S., Ciruela, F., 2017. Behavioral control by striatal adenosine A2A dopamine D2 receptor heteromers. Genes Brain Behav.

Tepper, J.M., Abercrombie, E.D., Bolam, J.P., 2007. Basal ganglia macrocircuits. Prog Brain Res 160, 3-7. 
Torvinen, M., Kozell, L.B., Neve, K.A., Agnati, L.F., Fuxe, K., 2004. Biochemical identification of the dopamine D2 receptor domains interacting with the adenosine A2A receptor. J Mol Neurosci 24, 173-180.

Trifilieff, P., Rives, M.L., Urizar, E., Piskorowski, R.A., Vishwasrao, H.D., Castrillon, J., Schmauss, C., Slattman, M., Gullberg, M., Javitch, J.A., 2011. Detection of antigen interactions ex vivo by proximity ligation assay: endogenous dopamine D2-adenosine A2A receptor complexes in the striatum. Biotechniques 51, 111-118.

Tsvetanova, N.G., Irannejad, R., von Zastrow, M., 2015. G protein-coupled receptor (GPCR) signaling via heterotrimeric G proteins from endosomes. J Biol Chem 290, 6689-6696. van Rijn, R.M., Brissett, D.I., Whistler, J.L., 2012. Emergence of functional spinal delta opioid receptors after chronic ethanol exposure. Biol Psychiatry 71, 232-238.

van Rijn, R.M., Whistler, J.L., 2009. The delta(1) opioid receptor is a heterodimer that opposes the actions of the delta(2) receptor on alcohol intake. Biol Psychiatry 66, 777-784.

Vaysse, P.J., Gardner, E.L., Zukin, R.S., 1987. Modulation of rat brain opioid receptors by cannabinoids. J Pharmacol Exp Ther 241, 534-539.

Verma, V., Hasbi, A., O'Dowd, B.F., George, S.R., 2010. Dopamine D1-D2 receptor Heteromer-mediated calcium release is desensitized by D1 receptor occupancy with or without signal activation: dual functional regulation by $\mathrm{G}$ protein-coupled receptor kinase 2. J Biol Chem 285, 35092-35103.

Vinals, X., Moreno, E., Lanfumey, L., Cordomi, A., Pastor, A., de La Torre, R., Gasperini, P., Navarro, G., Howell, L.A., Pardo, L., Lluis, C., Canela, E.I., McCormick, P.J., Maldonado, R., Robledo, P., 2015. Cognitive Impairment Induced by Delta9tetrahydrocannabinol Occurs through Heteromers between Cannabinoid CB1 and Serotonin 5-HT2A Receptors. PLoS Biol 13, e1002194. 
Vischer, H.F., Castro, M., Pin, J.P., 2015. G Protein-Coupled Receptor Multimers: A Question Still Open Despite the Use of Novel Approaches. Mol Pharmacol 88, 561-571.

Volkow, N.D., Morales, M., 2015. The Brain on Drugs: From Reward to Addiction. Cell 162, $712-725$.

Weber, E.T., Andrade, R., 2010. Htr2a Gene and 5-HT(2A) Receptor Expression in the Cerebral Cortex Studied Using Genetically Modified Mice. Front Neurosci 4.

Witkin, J.M., Statnick, M.A., Rorick-Kehn, L.M., Pintar, J.E., Ansonoff, M., Chen, Y., Tucker, R.C., Ciccocioppo, R., 2014. The biology of Nociceptin/Orphanin FQ (N/OFQ) related to obesity, stress, anxiety, mood, and drug dependence. Pharmacol Ther 141, 283-299.

Xie, W.Y., He, Y., Yang, Y.R., Li, Y.F., Kang, K., Xing, B.M., Wang, Y., 2009. Disruption of Cdk5-associated phosphorylation of residue threonine-161 of the delta-opioid receptor: impaired receptor function and attenuated morphine antinociceptive tolerance. $\mathrm{J}$ Neurosci 29, 3551-3564.

Yoshioka, K., Saitoh, O., Nakata, H., 2002. Agonist-promoted heteromeric oligomerization between adenosine A(1) and P2Y(1) receptors in living cells. FEBS Lett 523, 147-151.

Zou, S., Kumar, U., 2018. Cannabinoid Receptors and the Endocannabinoid System: Signaling and Function in the Central Nervous System. Int J Mol Sci 19. 


\section{Figure legends}

Figure 1: The mesocorticolimbic pathway in rodents.

The mesocorticolimbic pathway is involved in the reinforcing properties of drugs of abuse. Dopaminergic projections (DA) originating from the ventral tegmental area (VTA) are shown. Nacc, nucleus accumbens ; SN, substantia nigra; CeA, central amygdala; BNST, bed nucleus of the stria terminalis; LH, lateral hypothalamus.

\section{Figure 2: Heteromers modulate dopamine transmission}

(A) Native heteromers can modulate the direct striato-nigral pathway expressing the dopamine

$D_{1}$ receptor and the indirect striato-pallidal pathway expressing the dopamine $D_{2}$ receptor. $A$ third striatal output is composed of a discrete neuronal population of the ventral striatum expressing $\mathrm{D}_{1}-\mathrm{D}_{2}$ heteromers. Cross-talks within the heteromers and impact on neuronal activity are indicated. MSN, medium spiny neuron; Glu, glutamate.

(B) Neuroanatomical distribution of native heteromers that can modulate the mesocorticolimbic pathway and contribute to substance use disorder.

Figure 3: Altered expression of heteromers in the context of substance use disorder. Expression of heteromers is dynamic and affected by the physiological state and/or by drugs of abuse. Changes in heteromer expression identified in the mesocorticolimbic pathway by proximity ligation assay or selective antibodies are indicated.

Figure 4: Proposed model for adenosine $A_{2 a}$ receptor and dopamine $D_{2}$ receptor interactions in $\mathbf{A}_{2 \mathrm{a}}-\mathbf{D}_{2}$ heterotetramers.

The association of two $A_{2 a}-D_{2}$ heteromers generates a heterotetramer in which multiple interactions can simultaneously take place in the presence of ligands. Activation of the 
adenosine $A_{2 a}$ receptor by adenosine or an exogenous agonist negatively modulates $D_{2}$ agonist affinity and efficacy through physical interactions within the $\mathrm{A}_{2 \mathrm{a}}-\mathrm{D}_{2}$ heteromer. This allosteric modulation therefore dampens dopamine $\mathrm{D}_{2}$ receptor G-protein-dependent and independent signaling. Reciprocally, activation of the dopamine $\mathrm{D}_{2}$ receptor by dopamine or an exogenous agonist can negatively cross-modulate $\mathrm{A}_{2 \mathrm{a}}$ receptor affinity and signaling. Additional crosstalks take place at the level of the signaling cascades. They correspond to canonical interactions between stimulatory Gas dependent and inhibitory Gai/o dependent pathways. They modulate cAMP production in opposite directions. The heterotetrameric organization enables additional modulations by $\mathrm{A}_{2 \mathrm{a}}$ antagonists such as caffeine that would decrease the negative crosstalk on $\mathrm{D}_{2}$ receptor and reduce Gas dependent signaling (adapted from (Taura et al., 2017) (Navarro et al., 2018b) . 
Table 1

Heteromers with identified and potential implication in SUD

Abbreviations: Co-IP: co-immunoprecipitation, FRET: fluorescence resonance energy transfer, nd: not determined, PLA: proximity ligation assay

\begin{tabular}{|c|c|c|c|c|c|}
\hline Heteromer & \multicolumn{2}{|c|}{ In vivo physical proximity } & \multirow{2}{*}{$\begin{array}{c}\text { Impact on signaling } \\
\text { properties }\end{array}$} & \multirow[t]{2}{*}{ Postulated role in SUD } & \multirow[t]{2}{*}{ References } \\
\hline & Tissue & Techniques & & & \\
\hline \multicolumn{6}{|c|}{ Class A-Class A heteromers with established role in SUD } \\
\hline $\mathrm{A}_{2 \mathrm{a}}-\mathrm{D}_{2}$ & $\begin{array}{l}\text { Rat and } \\
\text { mouse } \\
\text { striatum }\end{array}$ & $\begin{array}{l}\text { Co-IP } \\
\text { PLA } \\
\text { Bivalent ligands } \\
\text { Electron microscopy } \\
\text { Time resolved- } \\
\text { FRET } \\
\text { Disruptive peptide }\end{array}$ & $\begin{array}{l}\text { Bidirectional negative cross- } \\
\text { talk } \\
\text { Co-internalization }\end{array}$ & $\begin{array}{l}\text { Habit formation } \\
\text { Drug relapse (cocaine reinstatement) } \\
\uparrow \text { Ethanol consumption } \\
\downarrow \text { Ethanol withdrawal } \\
\text { Caffeine stimulatory effect }\end{array}$ & $\begin{array}{l}\text { (Borroto-Escuela et al., 2017; } \\
\text { Borroto-Escuela et al., 2018; } \\
\text { El Yacoubi et al., 2001; } \\
\text { Feltmann et al., 2018; } \\
\text { Fernandez-Duenas et al., } \\
\text { 2015; He et al., 2016; Hillion } \\
\text { et al., 2002; Huang et al., } \\
\text { 2013; Marcellino et al., 2007; } \\
\text { Soriano et al., 2009; Trifilieff } \\
\text { et al., 2011) }\end{array}$ \\
\hline $\mathrm{D}_{2}$-sigma1 & 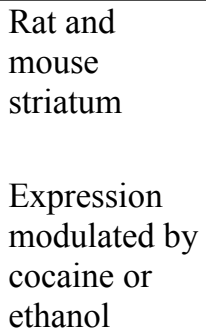 & $\begin{array}{l}\text { Co-IP } \\
\text { PLA }\end{array}$ & $\begin{array}{l}\text { Negative cross-talk on D2 } \\
\text { signaling }\end{array}$ & $\begin{array}{l}\text { Binds and mediates cocaine negative } \\
\text { cross-talk on } \mathrm{D}_{2} \text { signaling }\end{array}$ & $\begin{array}{l}\text { (Beggiato et al., 2017; } \\
\text { Borroto-Escuela et al., 2017; } \\
\text { Feltmann et al., 2018; Navarro } \\
\text { et al., 2013) }\end{array}$ \\
\hline $\mathrm{D}_{1}-\mathrm{D}_{2}$ & $\begin{array}{l}\text { Rat, mouse, } \\
\text { long-tail } \\
\text { macaque, } \\
\text { human } \\
\text { striatum }\end{array}$ & $\begin{array}{l}\text { Co-IP } \\
\text { FRET }\end{array}$ & $\begin{array}{l}\text { Gaq/11 signaling (BDNF } \\
\text { pathway) } \\
\uparrow B D N F\end{array}$ & $\begin{array}{l}\downarrow \text { Cocaine locomotor sensitization } \\
\downarrow \text { Cocaine reinforcing properties (CPP) }\end{array}$ & $\begin{array}{l}\text { (Hasbi et al., 2009; Hasbi et } \\
\text { al., 2018; Lee et al., 2004; Pei } \\
\text { et al., 2010; Perreault et al., } \\
\text { 2016; Rashid et al., 2007; } \\
\text { Rico et al., 2017) }\end{array}$ \\
\hline
\end{tabular}




\begin{tabular}{|c|c|c|c|c|c|}
\hline & $\begin{array}{l}\text { Expression } \\
\text { increased } \\
\text { with age }\end{array}$ & $\begin{array}{l}\text { PLA } \\
\text { Disruptive peptide }\end{array}$ & & $\begin{array}{l}\downarrow \text { Cocaine self-administration } \\
\downarrow \text { Cocaine seeking (reinstatement of self- } \\
\text { administration by drug or cue priming) } \\
\downarrow \text { Susceptibility to cocaine in adulthood } \\
\downarrow \text { Sucrose preference } \\
\downarrow \text { motivation (palatable food) } \\
\text { Drug induced neuroplasticity }\end{array}$ & \\
\hline $\mathrm{Mu}-\mathrm{D}_{1}$ & $\begin{array}{l}\text { Mouse } \\
\text { striatum }\end{array}$ & Co-IP & $\begin{array}{l}\text { Cross-antagonism on mu } \\
\text { signaling }\end{array}$ & Locomotor sensitization to opiates & (Tao et al., 2017) \\
\hline Mu-delta & $\begin{array}{l}\text { Mouse } \\
\text { hippocampus, } \\
\text { VTA } \\
\text { Expression } \\
\text { modulated by } \\
\text { chronic } \\
\text { morphine }\end{array}$ & $\begin{array}{l}\text { Co-IP } \\
\text { Heteromer specific } \\
\text { antibody } \\
\text { Bivalent ligand } \\
\text { Disruptive peptide }\end{array}$ & 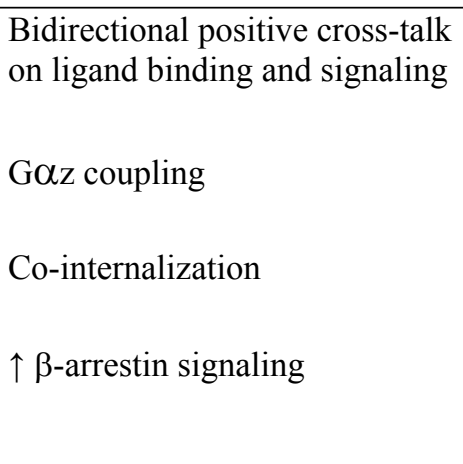 & $\begin{array}{l}\downarrow \text { tolerance } \\
\downarrow \text { physical dependence } \\
\downarrow \text { ethanol consumption }\end{array}$ & $\begin{array}{l}\text { (Daniels et al., 2005; } \\
\text { Derouiche et al., 2018; Erbs et } \\
\text { al., 2015; George et al., 2000; } \\
\text { Gomes et al., 2013; Gomes et } \\
\text { al., 2004; Gomes et al., 2011; } \\
\text { Gomes et al., 2000; Gupta et } \\
\text { al., 2010; He et al., 2011; } \\
\text { Kabli et al., 2010; Kabli et al., } \\
\text { 2013; Margolis et al., 2017; } \\
\text { Rozenfeld and Devi, 2007; } \\
\text { van Rijn and Whistler, 2009) }\end{array}$ \\
\hline Mu-Gal1 & Mouse VTA & Disruptive peptide & $\begin{array}{l}\text { Cross-antagonism on Gall } \\
\text { signaling } \\
\text { Negative cross-talk on mu } \\
\text { signaling }\end{array}$ & $\downarrow$ Opiates reinforcement and withdrawal & $\begin{array}{l}\text { (Hawes et al., 2008; Moreno } \\
\text { et al., 2017) }\end{array}$ \\
\hline $\mathrm{CB}_{1}-5 \mathrm{HT}_{2 \mathrm{a}}$ & $\begin{array}{l}\text { Mouse cortex, } \\
\text { hippocampus, } \\
\text { dorsal } \\
\text { striatum }\end{array}$ & $\begin{array}{l}\text { PLA } \\
\text { Disruptive peptide }\end{array}$ & $\begin{array}{l}\text { Bidirectional cross-antagonism } \\
\text { Negative cross-talk } \\
5 \mathrm{HT}_{2 \mathrm{a}} \text { coupling to } \mathrm{G \alpha i} / \mathrm{o}\end{array}$ & $\begin{array}{l}\uparrow \mathrm{THC} \text { physical dependence } \\
\uparrow \text { cognitive deficits associated to THC } \\
\text { (memory impairment, anxiety, reduced } \\
\text { social interaction) }\end{array}$ & (Vinals et al., 2015) \\
\hline
\end{tabular}




\begin{tabular}{|c|c|c|c|c|c|}
\hline & & & activation of mTOR pathway & & \\
\hline $\mathrm{CB}_{1}-\mathrm{A}_{2 \mathrm{a}}$ & Rat striatum & Co-IP & $\begin{array}{l}\text { Cross-antagonism on } \mathrm{CB}_{1} \\
\text { signaling }\end{array}$ & $\begin{array}{l}\text { THC locomotor sensitization } \\
\text { THC reinforcement (CPP) }\end{array}$ & $\begin{array}{l}\text { (Carriba et al., 2007; Ferreira } \\
\text { et al., 2015; Soria et al., 2004) }\end{array}$ \\
\hline \multicolumn{6}{|c|}{ Class A-Class A heteromers with potential role in SUD } \\
\hline $\mathrm{Mu}-\mathrm{CB} 1$ & Rat striatum & Electron microscopy & $\begin{array}{l}\text { Bidirectional negative cross- } \\
\text { talk } \\
\text { Bidirectional cross-antagonism }\end{array}$ & $\begin{array}{l}\text { Social play } \\
\downarrow \text { induced neuroplasticity }\end{array}$ & $\begin{array}{l}\text { (Manduca et al., 2016; Rios et } \\
\text { al., 2006 ; Rodriguez et al., } \\
\text { 2001) }\end{array}$ \\
\hline $\mathrm{CB}_{1}-\mathrm{CB}_{2}$ & $\begin{array}{l}\text { Rat striatum } \\
\text { Activated } \\
\text { microglia }\end{array}$ & PLA & $\begin{array}{l}\text { Bidirectional cross-antagonism } \\
\text { Negative cross-talk } \\
\text { Negative cross-talk in resting } \\
\text { microglia } \\
\text { Positive cross-talk in activated } \\
\text { microglia } \\
\text { Bidirectional cross-antagonism }\end{array}$ & $\begin{array}{l}\downarrow \text { psychostimulant-induced neurotoxicity } \\
\text { neuroinflammation }\end{array}$ & $\begin{array}{l}\text { (Callen et al., 2012) } \\
\text { (Navarro et al., 2018a) }\end{array}$ \\
\hline $\mathrm{D}_{3} / \mathrm{D}_{3 \mathrm{nf}}$ & Rat brain & Co-IP & $\begin{array}{l}\downarrow D_{3} \text { cell surface expression, } \\
\text { ligand binding }\end{array}$ & $\begin{array}{l}\text { Impulsivity } \\
\text { Sensitization to cocaine or nicotine }\end{array}$ & $\begin{array}{l}\text { (Karpa et al., 2000; } \\
\text { Nimchinsky et al., 1997; } \\
\text { Pritchard et al., 2006; Smith } \\
\text { et al., 2015) }\end{array}$ \\
\hline $\mathrm{D}_{1} / \mathrm{D}_{3}$ & Rat brain & Co-IP & $\begin{array}{l}\text { co-internalization } \\
\text { positive cross talk on D1 } \\
\text { signaling }\end{array}$ & $\begin{array}{l}\uparrow \text { Locomotor sensitization to } \\
\text { psychostimulants }\end{array}$ & $\begin{array}{l}\text { (Fiorentini et al., 2008; } \\
\text { Marcellino et al., 2008) }\end{array}$ \\
\hline $\mathrm{D}_{1}-\mathrm{H}_{3}$-sigmal & $\begin{array}{l}\text { Rat and } \\
\text { mouse } \\
\text { striatum }\end{array}$ & $\begin{array}{l}\text { Co-IP } \\
\text { PLA }\end{array}$ & $\begin{array}{l}\text { Bidirectional cross-antagonism } \\
\text { Negative cross-talk on } \mathrm{D}_{1} \\
\text { signaling ( } \mathrm{D}_{1} \text { coupling to } \\
\mathrm{G} \alpha \mathrm{i} / \mathrm{o}, \mathrm{H}_{3} \text { activation of } \\
\text { ERK1/2) }\end{array}$ & $\begin{array}{l}\text { Ex vivo regulation of striatal GABAergic } \\
\text { activity by acute and chronic cocaine } \\
\text { neuroprotective }\end{array}$ & $\begin{array}{l}\text { Ferrada et al., 2009; } \\
\text { Kononoff Vanhanen et al., } \\
\text { 2016; Moreno et al., 2011a; } \\
\text { Moreno et al., 2014) }\end{array}$ \\
\hline
\end{tabular}




\begin{tabular}{|c|c|c|c|c|c|}
\hline & & & $\begin{array}{l}\text { sigma1 mediates cocaine } \\
\text { disruption of bidirectional } \\
\text { cross-antagonism and negative } \\
\text { cross-talk on } \mathrm{D}_{1} \text { signaling }\end{array}$ & & \\
\hline $\mathrm{A}_{1}-\mathrm{A}_{2 \mathrm{a}}$ & Rat striatum & $\begin{array}{l}\text { Co-IP } \\
\text { Electron microscopy }\end{array}$ & $\downarrow \mathrm{A}_{2 \mathrm{a}}$ affinity for caffeine & Caffeine stimulant effects & (Ciruela et al., 2006) \\
\hline \multicolumn{6}{|c|}{ Class A-class $\mathrm{C}$ heteromers with a role in SUD } \\
\hline $5 \mathrm{HT}_{2 \mathrm{a}}-\mathrm{mGlu2}$ & $\begin{array}{l}\text { Mouse, } \\
\text { human cortex }\end{array}$ & $\begin{array}{l}\text { Co-IP } \\
\text { Electron microscopy } \\
\text { Interfering peptide }\end{array}$ & $\begin{array}{l}\text { Modulation of } \mathrm{G} \alpha \mathrm{i} / \mathrm{o}-\mathrm{G} \alpha \mathrm{q} / 11 \\
\text { coupling in favor of } \mathrm{G} \alpha \mathrm{i} / \mathrm{o}\end{array}$ & Effects of hallucinogens (LSD) & $\begin{array}{l}\text { (Fribourg et al., 2011; } \\
\text { Gonzalez-Maeso et al., 2008; } \\
\text { Moreno et al., 2011b; Moreno } \\
\text { et al., 2012) }\end{array}$ \\
\hline $\mathrm{A}_{2 \mathrm{a}}-\mathrm{mGlu} 5$ & $\begin{array}{l}\text { Rat, mouse } \\
\text { striatum } \\
\text { Expression } \\
\text { modulated by } \\
\text { cocaine }\end{array}$ & $\begin{array}{l}\text { Co-IP } \\
\text { PLA }\end{array}$ & Positive cross-talk & $\downarrow$ Sensitization to psychostimulants & $\begin{array}{l}\text { (Beggiato et al., 2016; } \\
\text { Borroto-Escuela et al., 2017; } \\
\text { Ferre et al., 2002 ; He et al., } \\
\text { 2016) }\end{array}$ \\
\hline $\mathrm{M}_{2}-\mathrm{GABA}_{\mathrm{b} 2}$ & Rat cortex & Co-IP & $\uparrow \mathrm{M}_{2}$ signaling & Cocaine discrimination & $\begin{array}{l}\text { (Boyer et al., 2009; Joseph } \\
\text { and Thomsen, 2017) }\end{array}$ \\
\hline \multicolumn{6}{|c|}{ GPCR-ion channel heteromers with potential role in SUD } \\
\hline $\begin{array}{l}\mathrm{D}_{2}-\mathrm{N} \text {-type } \\
\mathrm{Ca}^{2+} \text { channel } \\
\end{array}$ & Rat striatum & Co-IP & $\downarrow$ Channel activity & nd & $\begin{array}{l}\text { (Kisilevsky and Zamponi, } \\
\text { 2008) }\end{array}$ \\
\hline $\begin{array}{l}\mathrm{D}_{1}-\mathrm{N} \text {-type } \\
\mathrm{Ca}^{2+} \text { channel } \\
\end{array}$ & Rat PFC & Co-IP & $\downarrow$ Channel activity & nd & (Kisilevsky et al., 2008) \\
\hline $\begin{array}{l}\text { ORL1-N-type } \\
\mathrm{Ca}^{2+} \text { channel }\end{array}$ & Rat brain & Co-IP & $\downarrow$ Channel activity & nd & $\begin{array}{l}\text { (Beedle et al., 2004; Evans et } \\
\text { al., 2010) }\end{array}$ \\
\hline $\begin{array}{l}\mathrm{Mu}-\mathrm{NMDA} \\
\mathrm{NR} 1\end{array}$ & Mouse PAG & Co-IP & $\begin{array}{l}\text { Modulation NMDA-CAMKII } \\
\text { pathway }\end{array}$ & nd & $\begin{array}{l}\text { (Rodriguez-Munoz et al., } \\
\text { 2012) }\end{array}$ \\
\hline $\mathrm{D}_{1}$-NMDA & $\begin{array}{l}\text { Rat striatum, } \\
\text { hippocampus }\end{array}$ & Co-IP & $\begin{array}{l}\uparrow \mathrm{D} 1 \text { surface expression } \\
\text { positive cross-talk on D1 } \\
\text { signaling }\end{array}$ & nd & $\begin{array}{l}\text { (Fiorentini et al., 2003; Pei et } \\
\text { al., 2004) }\end{array}$ \\
\hline
\end{tabular}




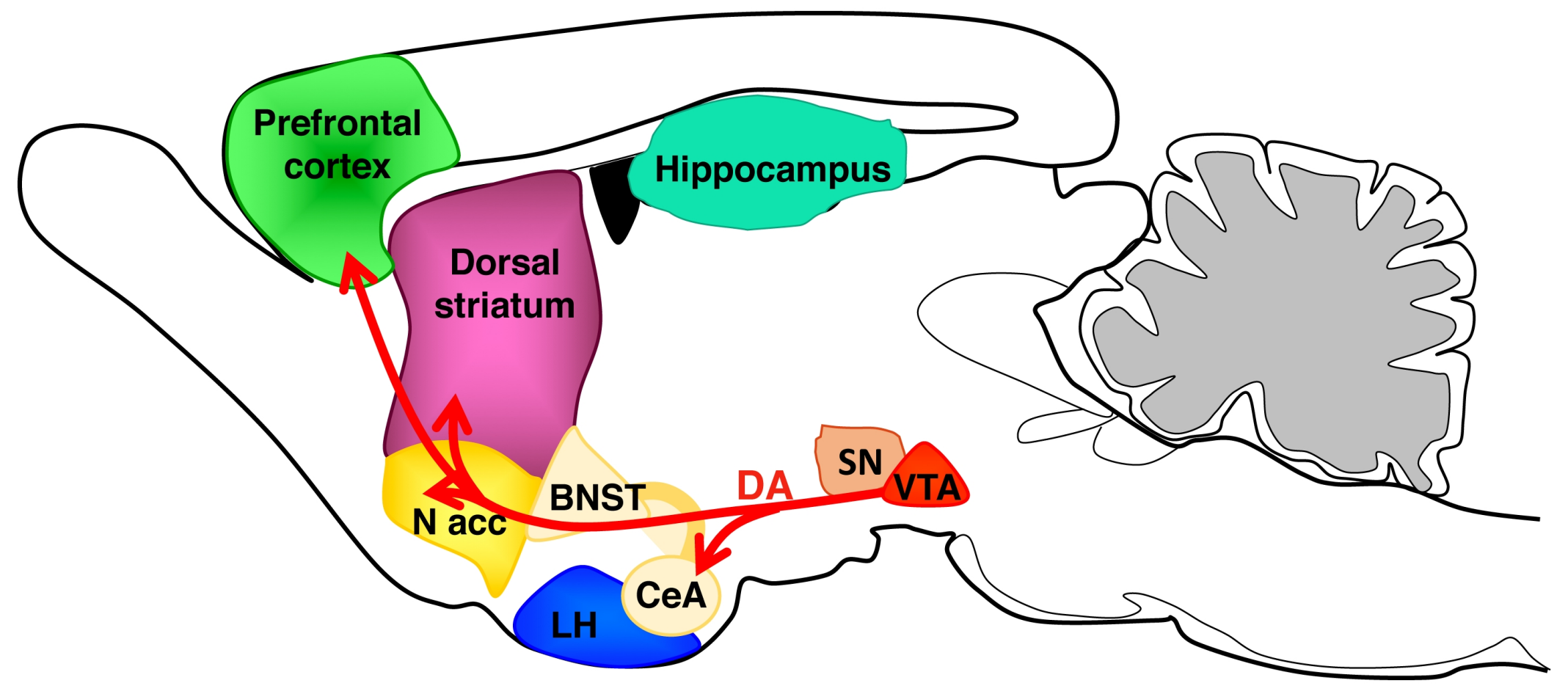


A

Striatopallidal Indirect Pathway
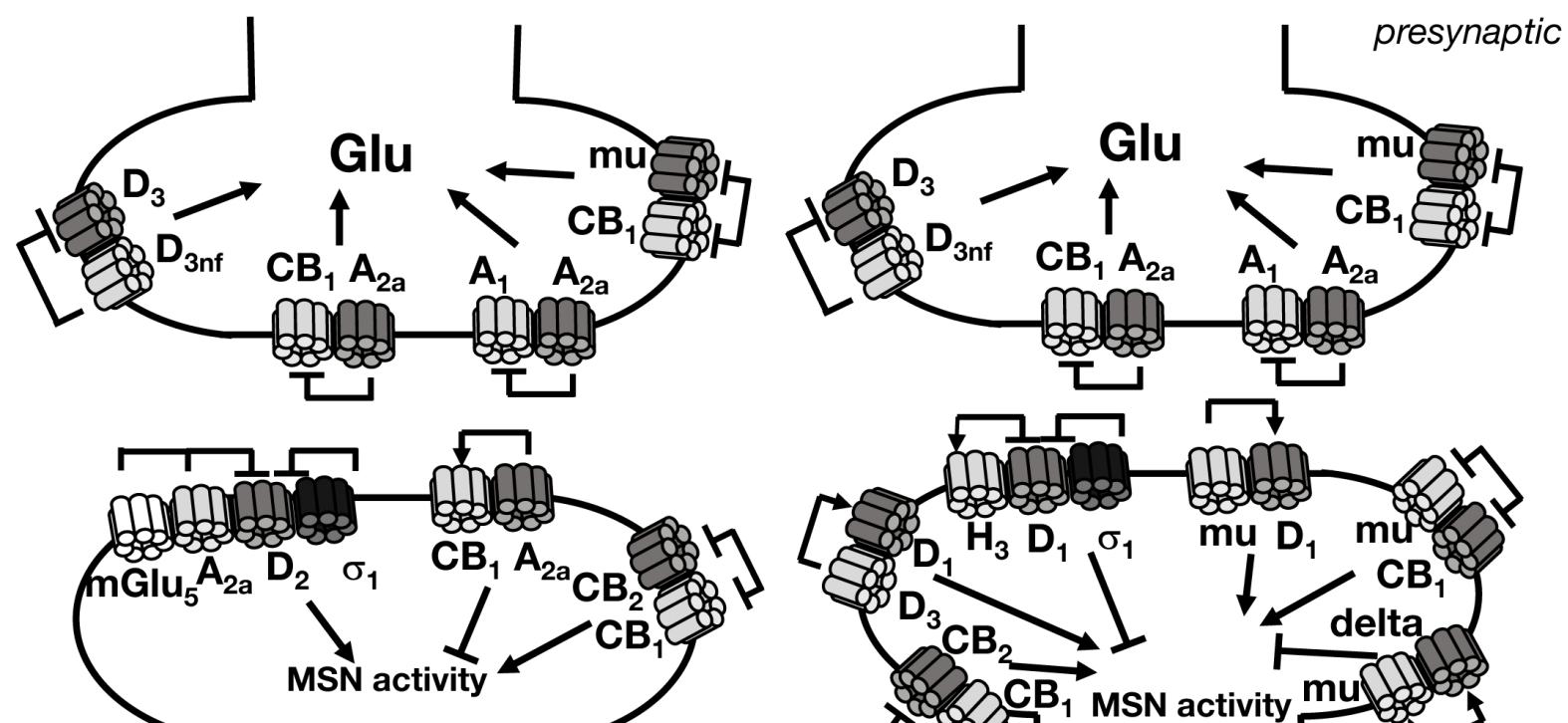

GABA Enkephalin

B

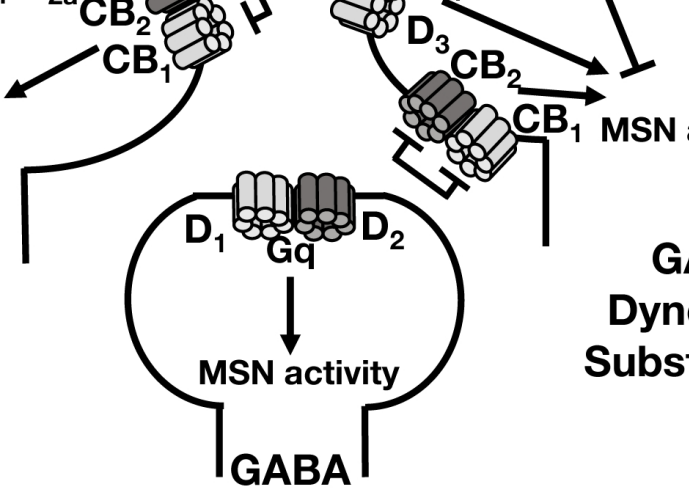

Striatonigral

Direct Pathway

Glutamate

Enkephalin

Dynorphin
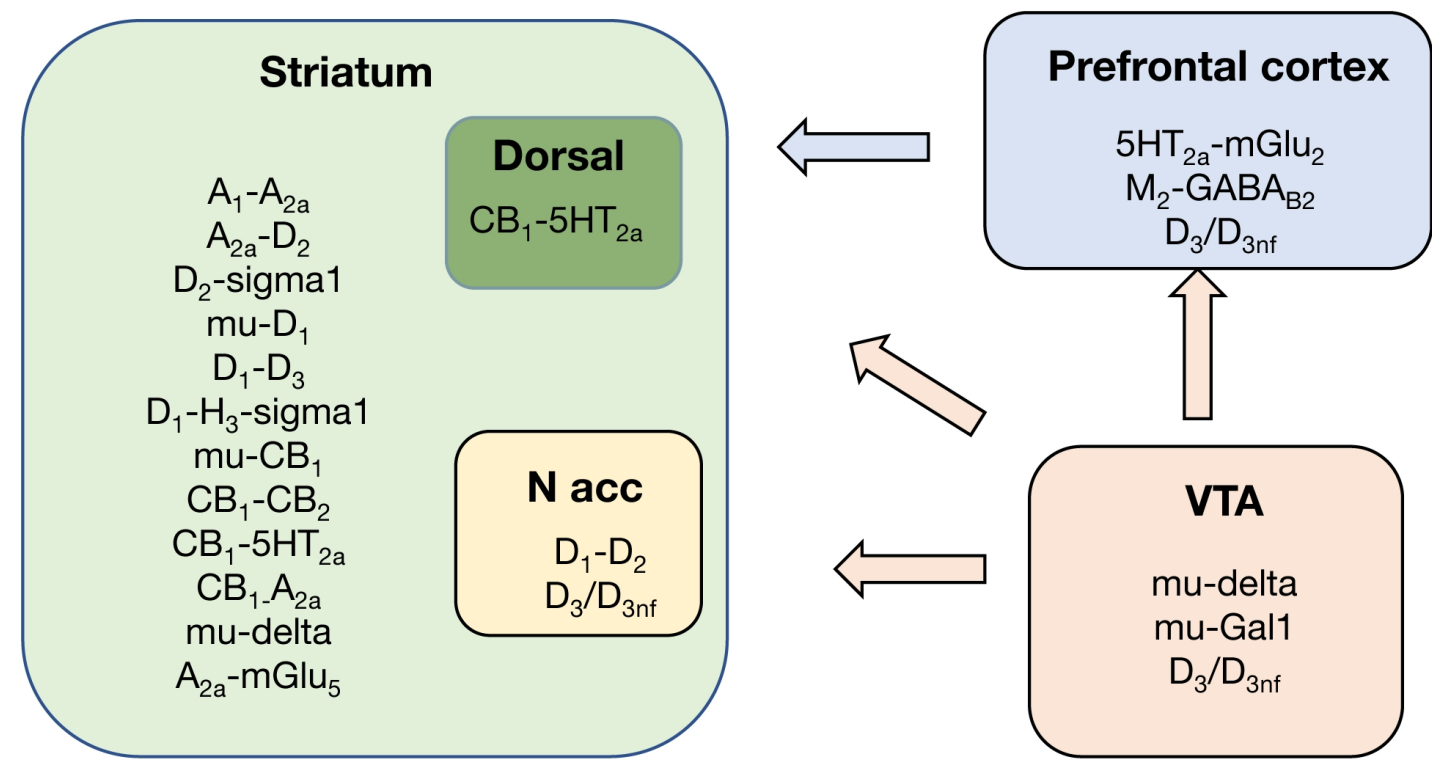


\section{Dorsal striatum}

Cocaine

$\leftrightarrow A_{2 a}-D_{2}$

$\downarrow D_{2}$-sigma1

Alcohol

Habit formation

$\uparrow \mathrm{A}_{2 \mathrm{a}}-\mathrm{D}_{2}$ $\uparrow A_{2 \mathrm{a}}-\mathrm{D}_{2}$

$\checkmark D_{2}$-sigma1

Chronic morphine

$\uparrow$ mu-delta

\section{Nucleus accumbens}

Cocaine
$A_{2 a}-D_{2}$ (shell)
$\mathrm{D}_{2}$-sigma1 (shell)
Ageing
$\uparrow D_{1}-D_{2}$ (shell)

Alcohol

$\mathrm{A}_{2 \mathrm{a}}-\mathrm{D}_{2}$ (shell)

Chronic morphine $\uparrow$ mu-delta

\section{VTA}

Chronic morphine

$\uparrow$ mu-delta 


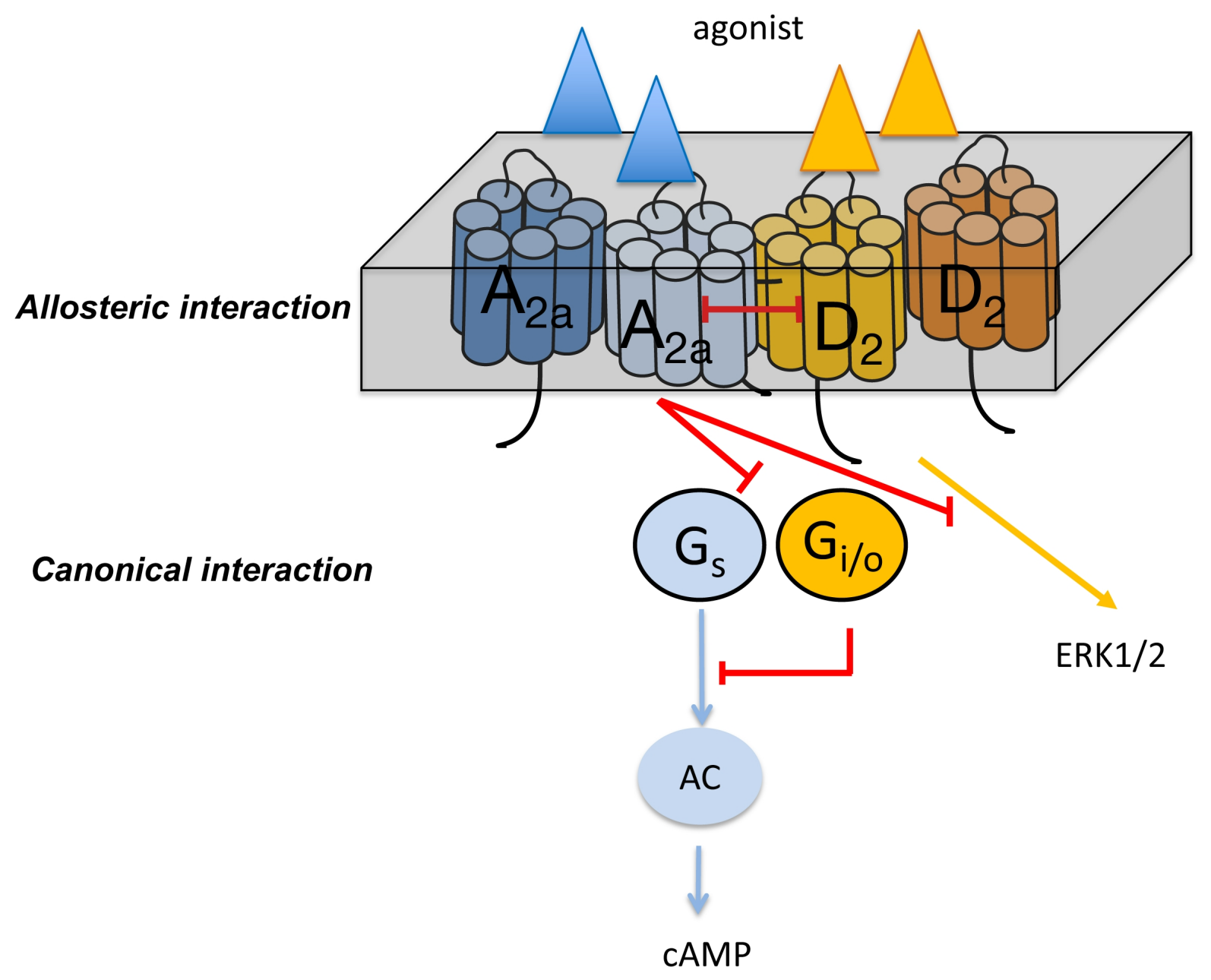

